\title{
Postmortem Durability and Population Dynamics Affecting the Fidelity of Brachiopod Size-Frequency Distributions
}

\author{
ADAM TOMAŠOVÝCH \\ Institut für Paläontologie, Würzburg Universität, Pleicherwall 1, 97070 Würzburg, Germany, E-mail: \\ adam.tomasovych@mail.uni-wuerzburg.de
}

PALAIOS, 2004, V. 19, p. 477-496

Actualistic comparison of size-frequency distributions (SFDs) of life and death assemblages of the brachiopod Terebratalia transversa from the San Juan Archipelago, Washington State, USA, revealed significant differences in the fidelity of SFDs between hard-bottom and mixed-bottom habitats. In relatively shallow (36-55 m), high-energy, and hard-bottom settings with pebbles and cobbles, the SFD of death assemblages is shaped primarily by taphonomic processes and its compositional fidelity is very low. Juvenile specimens are absent, probably due to winnowing and mechanical destruction. In deeper (64-84 m), low-energy, and mixed-bottom settings with a high proportion of soft substrata, population dynamics have a greater influence on the SFD of death assemblages; compositional fidelity is relatively high and original between-habitat variations in the population structure are preserved. Shell maceration probably is an important destruction process in both settings. In addition to environmental factors, intrinsic factors involving postmortem durability and population dynamics (related to timing and frequency of dead-shell production) are important in influencing preservation potential and fidelity of brachiopod death assemblages. There is differential preservation between small and large specimens. Smaller specimens are always characterized by better preservation and probably are dominated by cohorts that died most recently. Without continual input of juveniles, these soon will disappear from the death assemblage. More durable, larger specimens are characterized by higher taphonomic damage. These data point to size-selective taphonomic processes, leading to disharmonious time-averaging with respect to the relative abundance of size classes. Based on the assumption of short-term variations in population structure and evidence about high rate of destruction of juveniles and differential postmortem durabilities of juveniles and adults, high fidelity of SFDs of death assemblages in deeper, mixed-bottom settings is also the consequence of limited time-averaging. In contrast to previous studies of SFDs of death assemblages, it is emphasized that in addition to extrinsic factors, the interplay of inherent durability and frequency of dead-shell production is important in understanding their fidelity. A simple deterministic model predicts that on a short time scale, subtle differences in rate of destruction and recruitment frequency (related to rate of dead-shell production) lead to quite different probability of preservation of juveniles, even with the same mortality and growth rate. In settings comparable to the San Juan Archipelago, preservation potential of punctate brachiopods will depend on the rate of burial. This fact has a significant implication for distribution pattern of fossil punctate brachiopods, because unless rapidly buried, their distribution patterns can be strongly biased.

\section{INTRODUCTION}

Evaluation of the fidelity of fossil assemblages is one of the most important aspects of studies of the quality of the fossil record. The size-frequency distribution (SFD) of life and death assemblages is used (1) as a tool in the interpretation of population dynamics in ecology and paleoecology (Hallam, 1967, 1972; Powell and Stanton, 1996; Powell et al., 1998, 2001; Simões and Kowalewski, 1998; Staff and Powell, 2000; Fürsich et al., 2001; Bitner, 2002), in spite of several problems related to age determination, variations in growth rate, and time-averaging; and (2) as a proxy for inference of taphonomic processes (Powell et al., 1989; Kidwell and Bosence, 1991). The second approach is related mainly to the estimation of one aspect of compositional fidelity of death assemblages-the quantitative faithfulness of the representation of size (or age) classes to the original biological signal (Fagerstrom, 1964; Cummins et al., 1986a; Behrensmeyer et al., 2000). This is of special importance because this approach offers insight into the origins of postmortem bias and helps in understanding the dynamics of the formation of death assemblages (Kidwell, 2002). Both approaches are inter-related, since the evaluation of intensity of taphonomic processes and their effects on the SFD of a death assemblage is crucial for assessment of the potential of a SFD for inference of population structure.

However, the transition from life to death assemblage is controlled by several variables, including the mortality rate and variations in growth rate, and thus depends partly on understanding the population dynamics. The intensity of taphonomic bias is influenced by several complex variables and primarily depends on intrinsic factors of the original population (abundance, durability) and extrinsic environmental (physical, chemical, and biological) processes operating over a wide range of scales (Kowalewski, 1996a; Behrensmeyer et al., 2000). Therefore, for unequivocal inference of the taphonomic overprint of the SFD of a death assemblage, it is important to obtain independent data from shell preservation or other sources of taphonomic information.

Many previous fidelity studies are concerned with assemblage-level features (e.g., species richness, evenness, 0883-1351/04/0019-0477/\$3.00 
or rank abundances), but the reliability of size-/age-class representation is still poorly known. For example, many studies of fidelity of modern death assemblages of marine invertebrates resulted in finding that preservation processes can differ substantially even though environmental differences might otherwise be subtle (e.g., Pandolfi and Greenstein, 1997b). However, the number of comparative studies across environmental boundaries is relatively low (e.g., Flessa and Fürsich, 1991; Zuschin et al., 2000; Zuschin and Oliver, 2003). Therefore, actualistic estimates of the compositional fidelity within and between environments should form a key focal area for taphonomic research.

The main goal of this study is to assess the fidelity and difference between SFDs of life and death assemblages of Terebratalia transversa in a temperate, siliciclastic setting of the Pacific Northwest. The results address the extent to which original variations of SFDs related to population ecology can be preserved in death assemblages and whether there is a difference in taphonomic preservation of death assemblages between various bathymetric settings. Evaluation of the spatial and temporal distribution patterns of articulate brachiopods inevitably relies on detailed assessment of variations in their preservation potential. In spite of their extensive fossil record, there are few actualistic data for postmortem durability from experimental or field measurements and from actualistic live/ dead comparisons (Lee, 1978; Stewart, 1981; Noble \& Logan, 1981; Witman and Cooper, 1983; Collins, 1986; Tunnicliffe and Wilson, 1988; Daley, 1993). Therefore, in this study, SFD is tested as a tool for the evaluation of one aspect of the compositional fidelity (Behrensmeyer et al., 2000) related to the size-/age-class composition of brachiopod death assemblages-a very important topic for estimation of taphonomic loss and understanding whether taphonomic processes have a significant effect on distribution patterns of fossil brachiopods.

In the first part of this project, a case study based on comparison of SFDs of Terebratalia transversa life and death assemblages is undertaken. The results and discussion are subdivided into four parts, including: (1) betweensetting comparisons of life assemblages; (2) between-setting comparison of death assemblages; (3) within-setting comparisons of life and death assemblages; and (4) the effect of shell preservation on SFDs. One of the consequences of the first part is that extrinsic factors substantially determine the fidelity of the death assemblages but do not explain all variation in the fidelity patterns. In fact, based on data about short-term variations in population dynamics and differential preservation of juveniles and adults, the SFD of a time-averaged death assemblage should not mirror the SFD of a snapshot life assemblage. Therefore, in order to understand the potential role of intrinsic factors, this paper addresses the interaction between postmortem durability and population dynamics, and its influence on compositional fidelity. Hence, in the second part, a simple deterministic model describing differential effects of destruction rate and dead-shell production rate on preservation potential of juveniles is developed. In the third part, implications of this project for the fossil record are discussed.

\section{METHODS}

\section{Geographic Setting}

SFDs of brachiopod life and death assemblages were compared on samples from several different environmental settings in the San Juan Archipelago (Washington State, USA; Fig. 1). The tidal range in Puget Sound is about $3.3 \mathrm{~m}$, which generates strong tidal currents in the sounds and narrows (Lie, 1974), leading to good circulation, relatively stable water temperatures, and normalmarine salinity throughout the whole year (Thomson, 1981). Five subtidal habitats (Table 1) representing a bathymetric gradient from 36 to $84 \mathrm{~m}$ were sampled by dredging during July 2002. Weights of the 0.063-1 mm fraction are reported in Table 1 in order to compare relative proportions of fine sediment between dredge samples. Three locations were sampled (Fig. 1). (1) A moderately steep slope on the eastern side of the San Juan Channel (the western side of Lopez Island), near Rock Point Beach, Lopez Island. Three samples were taken from the slope transect, in a direction approximately perpendicular to the shoreline at Rock Point. Sample 1-a topographically uneven, relatively steep bottom at 36 to $45 \mathrm{~m}$ depth; the substrate predominantly consisted of rounded pebbles and cobbles, shell debris was less common. Sample 2-poorly sorted, mixed substrate consisting of unconsolidated siltysandy sediment with shell fragments and bioclastic debris; granules, pebbles, and small cobbles are less abundant. Sample 3-substrate similar to Sample 2; poorly sorted, mixed fine-grained sand and silt, granules and pebbles were less common, shell fragments and fine bioclastic debris were abundant. (2) Western side of the San Juan Channel, eastern slope of San Juan Island. Sample 4poorly sorted fine-grained sandy and silty sediment with abundant shell debris; life assemblage dominated by clusters of Modiolus modiolus. (3) Narrow, about 300-m-wide channel between Spieden Island on the north and Sentinel Island on the south, with relatively steep rocky slopes. Sample 5-rapid depth changes from 38 to 55 m over short distances indicate uneven topography; the substrate consisted of large basaltic cobbles and boulders and mollusk shell debris.

\section{Laboratory Analyses}

Two punctate brachiopods, including Terebratalia transversa (Sowerby) and Terebratulina unguicula (Carpenter), were found in the dredge samples. Although characterized by high morphologic variation, adult specimens of Terebratalia transversa are easily identifiable by the presence of a sulcate anterior margin, attrite pedicle foramen, sharp beak ridges, obsolete dental plates, and a sessile pedicle collar (Atkins, 1959; Bernard, 1972). Juvenile shells of Terebratulina can be distinguished from Terebratalia by their crenulated anterior commissure, elevated pedicle collar, hypothyrid pedicle foramen, wide cardinal area, and auriculate posterior margin.

The dredged material was sieved and divided into five fractions $(0.063,0.991,2.3,4$, and $12 \mathrm{~mm})$. Live and dead specimens were sorted from the four larger fractions, in addition to picking of macroscopic specimens directly from the dredge. Because the project length was not sufficient 

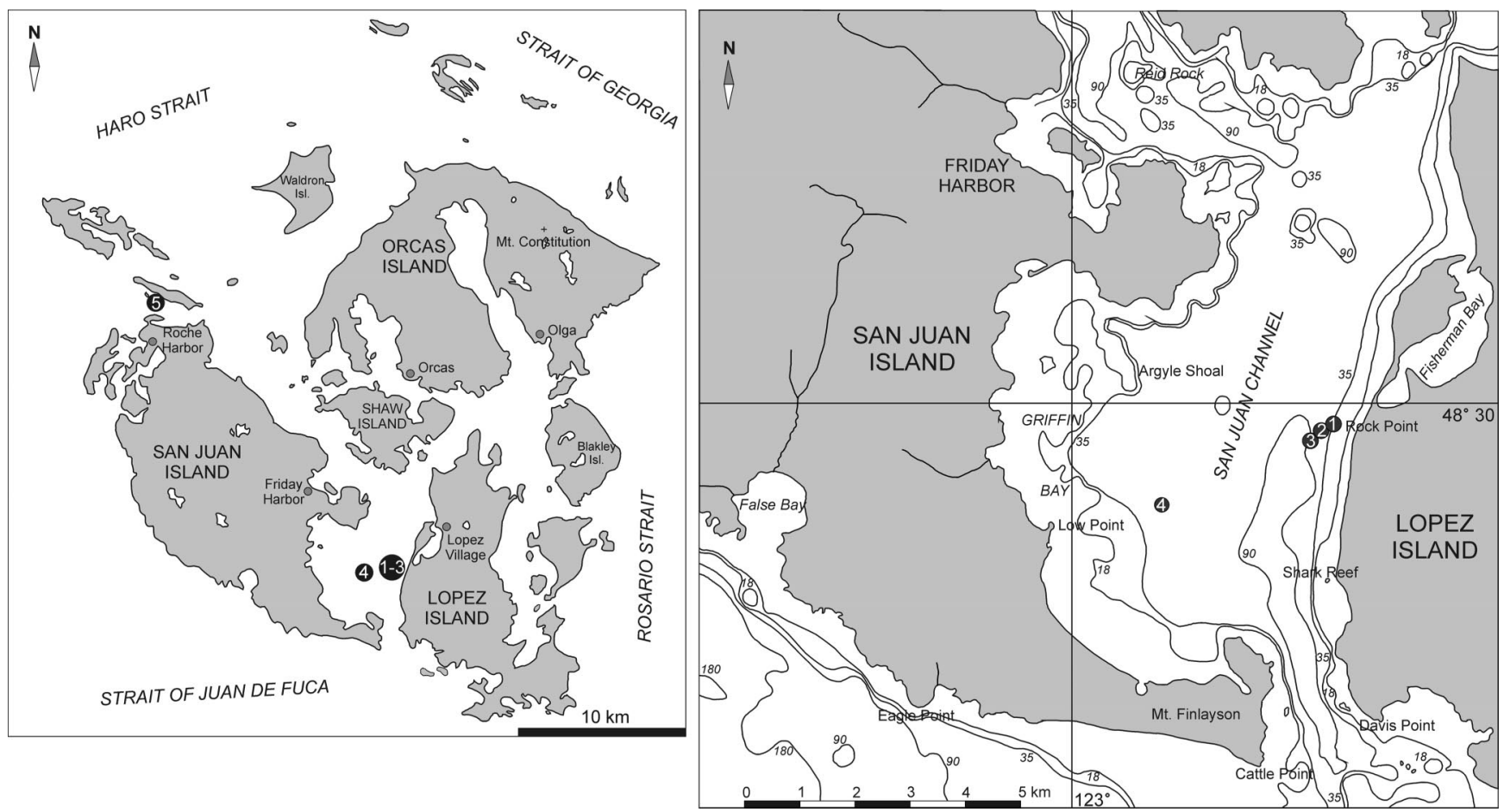

FIGURE 1-Schematic map of the study area with dredging localities. (A) San Juan Archipelago. (B) Detailed view of the San Juan Channel.

enough for processing the smallest size fraction $(<0.991$ $\mathrm{mm}$ ), the size class $<0.9 \mathrm{~mm}$, often very common in life assemblages, was excluded from the comparative analysis of life and death assemblages. Detailed inspection of rocky gravels and live and dead shells under a binocular microscope was necessary in order to obtain live juvenile individuals. Despite this effort, juveniles are probably still underrepresented. Both disarticulated valves and articulated shells were counted (XNI approach-maximum number of individuals assuming that that sampling domain is larger than the number of body parts in the death assemblage; Gilinsky and Bennington, 1994). In order to estimate the relative contribution of disarticulated valves and articulated shells in SFDs, proportions of both taphonomic grades were superimposed in SFDs and compared (see results). Length, width, and thickness measurements of valves or whole shells were taken in the laboratory for each specimen. Binary taphonomic scoring (presence/absence) of articulation, fragmentation, and internal-surface alteration was conducted. Internal-surface alteration was scored using high (50x) magnification under a binocular microscope. Valve surfaces with pristine secondary shell mosaics were scored as unaltered, whereas valve surfaces with a jagged appearance and loose secondary fibers were scored as altered. Fragmented specimens were measured if length or width were reliable to the nearest $1 \mathrm{~mm}$. In total, 1071 specimens were analyzed. Dimensions of specimens larger than $6 \mathrm{~mm}$ were measured using digital calipers; smaller specimens were measured to a resolution of $0.01 \mathrm{~mm}$ using an ocular micrometer mounted in a dissecting microscope. Each specimen was assigned a unique identification number. SFD data were plotted as histograms and compared using statistical descriptions and non-parametric multisample tests in SAS $\odot$ v. 8.12 (SAS Institute, 2001). The data used for these analyses are available from the SEPM electronic data repository $<$ http: //www.sepm.org/archive/index.html>.

The Kolmogorov-Smirnov test is based on a maximum relative difference between the two relative cumulative curves derived from tested samples. It evaluates the null hypothesis that two samples came from a single distribution in terms of their overall shape. The cumulative frequencies in the Kolmogorov-Smirnov test are normalized with respect to sample size. The Wilcoxon test can be considered as a non-parametric equivalent of the paired t-test and is used to test whether the values in two samples dif-

TABLE 1-Depth intervals, weights (in grams) of dredged sediment fraction, and geographic coordinates of individual samples.

\begin{tabular}{|c|c|c|c|c|c|}
\hline Sample & 1 & 2 & 3 & 4 & 5 \\
\hline Depth & $36-45 \mathrm{~m}$ & $64 \mathrm{~m}$ & $73 \mathrm{~m}$ & $84 \mathrm{~m}$ & $38-55 \mathrm{~m}$ \\
\hline $0.063-1 \mathrm{~mm}$ & $43 \mathrm{~g}$ & $706 \mathrm{~g}$ & $1891 \mathrm{~g}$ & $2408 \mathrm{~g}$ & $0 \mathrm{~g}$ \\
\hline \multirow[t]{2}{*}{ Start of dredge } & $\mathrm{N} 48^{\circ} 29.826^{\prime}$ & $\mathrm{N} 48^{\circ} 29.900^{\prime}$ & $\mathrm{N} 48^{\circ} 29.926^{\prime}$ & N $48^{\circ} 29.317^{\prime}$ & N $48^{\circ} 38.381^{\prime}$ \\
\hline & W $122^{\circ} 56.689^{\prime}$ & W $122^{\circ} 56.790^{\prime}$ & W $122^{\circ} 56.846^{\prime}$ & W $122^{\circ} 59.272^{\prime}$ & W $123^{\circ} 08.731^{\prime}$ \\
\hline \multirow[t]{2}{*}{ End of dredge } & $\mathrm{N} 48^{\circ} 29.945^{\prime}$ & N $48^{\circ} 29.692^{\prime}$ & N $48^{\circ} 29.774^{\prime}$ & $\mathrm{N} 48^{\circ} 28.959^{\prime}$ & $\mathrm{N} 48^{\circ} 38.533^{\prime}$ \\
\hline & W $122^{\circ} 56.616^{\prime}$ & W $122^{\circ} 56.856^{\prime}$ & W $122^{\circ} 56.886^{\prime}$ & W $122^{\circ} 59.000^{\prime}$ & W $123^{\circ} 09.033^{\prime}$ \\
\hline
\end{tabular}




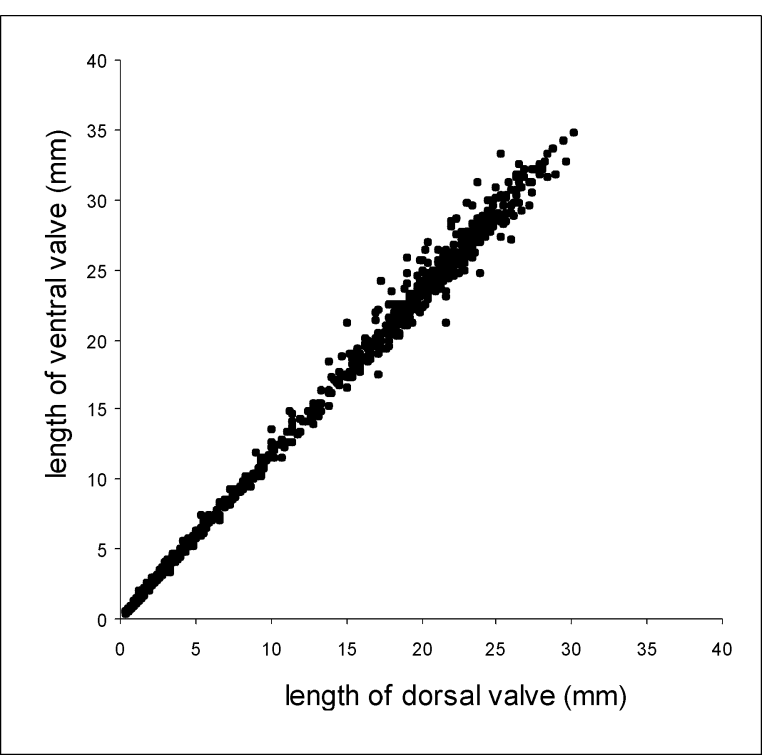

FIGURE 2-Bivariate plot of ventral and dorsal valve lengths, derived from measurements $(n=936)$ of whole live and dead shells. The least-square regression was used in order to predict the length of ventral valve from the length of dorsal valve.

fer in their medians. Because some sample sizes are small, the median is a more reliable estimator of central tendency. Because several independent statistical tests were performed simultaneously, a given alpha value may be appropriate for each individual comparison, but is not suitable for the set of all comparisons. Therefore, the Bonferroni correction was used as a multiple-comparison correction, where the alpha value is lowered to account for the number of comparisons being performed. The length of the ventral valve was used as the representative dimension for SFD histograms. If only the dorsal valve were preserved, the length of ventral valve was estimated using the equation determined from simple regression analysis (least squares method), which was derived from measurements of live and dead whole shells (Fig. 2) using the following equation:

$$
\mathrm{Lv}=0.18993+1.15874(\mathrm{Ld})
$$

where $\mathrm{Lv}$ is length of ventral valve, $\mathrm{Ld}$ is length of dorsal valve, 0.18993 represents the intercept value (standard error 0.0407, t-test, $\mathrm{p}<0.0001$ ), and 1.15874 represents the slope of the regression line (standard error $0.0026, \mathrm{t}$ test, $\mathrm{p}<0.0001)$. The coefficient of determination $\left(\mathrm{R}^{2}\right)$ is 0.9952 .

\section{BETWEEN-SETTING VARIATION OF LIFE ASSEMBLAGES}

\section{Results}

Based on depth, substrate type, and energy level, samples were divided into two main groups: samples 1 and 5 from relatively shallow, high-energy settings were characterized by a high proportion of hard substrata (cobbles, pebbles, and boulders; 36-55 m), and Samples 2, 3, and 4, from deeper, mixed-bottom, and low-energy settings, were characterized by higher abundance of fine-grained silty and sandy unconsolidated sediments and bioclastic debris (64-84 m). All these settings are subtidal.

The SFDs of most of the life assemblages are characterized by a distinct juvenile peak (Fig. 3). The life assemblage from Sample 1 exhibits a relatively symmetrical and platykurtic distribution (Table 2, Fig. 3). The life assemblage from Sample 5 (Fig. 3) has a distinct juvenile peak between 1 and $2 \mathrm{~mm}$ and a second peak between 22 and 25 $\mathrm{cm}$. A weak third peak appears between 8 and $9 \mathrm{~mm}$. In Samples 2 and 3, life assemblages are characterized by bimodal and right-skewed distributions, with a high number of small specimens between 0.5 and $4 \mathrm{~mm}$ (Fig. 3). On the scale of 3-4 mm intervals, relatively well-defined higher-frequency size classes defining a polymodal pattern are distinguishable. Sample 4, characterized by the dominance of Modiolus modiolus, contained only juvenile and subadult specimens under $10 \mathrm{~mm}$, and its distribution is strongly right-skewed and unimodal (Fig. 3).

Multisample pairwise comparisons between individual settings demonstrate significant differences in the SFD of life assemblages of Sample 4 and all other life assemblages (Table 3) for both Kolmogorov-Smirnov and Wilcoxon twosample tests. SFDs of Samples 2 and 3 also exhibit a significant difference. In spite of the differences in environmental setting (substrate type, energy level), the SFD of the life assemblage from Sample 5 is not significantly different from that from Sample 2. However, the adult peak of the assemblage from Sample 2 is shifted to the right $(25-28 \mathrm{~mm})$ in comparison to that from Sample 5 (22-24 $\mathrm{mm})$.

\section{Discussion}

The smaller juvenile peak from Sample 1 may be attributable to a higher intensity of grazing/predation and/or spatial competition in the shallowest habitats, indicated by the small proportion of live juveniles on empty surfaces. Polyplacophorans and limpets, which are relatively abundant in this sample, are candidates for grazing. In this sample, $57 \%$ of juveniles were found attached in crevices. The proportion of juvenile specimens in crevices decreases with increasing depth (Sample $2=28.5 \%$; Sample $3=$ 26.5\%). Similarly, Collins (1991) indicated that grazing pressure and spatial competition probably accounted for the elevated mortality levels of Terebratulina retusa. The other possibility for low abundance of juveniles could be local recruitment failure (Thayer 1975). Interestingly, the SFD of life assemblages from Sample 5 (hard-bottom) and Sample 2 (mixed-bottom habitats) are relatively similar in terms of their bimodality and skewness. The unimodal and strongly right-skewed SFD of Sample 4 from the Modiolus-dominated macrobenthic assemblage is characterized by the absence of specimens that are bigger than 10 $\mathrm{mm}$. This indicates some adverse ecological factor inhibiting individuals from reaching adulthood at this locality, perhaps related to the monotypic substrate type (substrate failure) and their specialized life strategy (sensu Richardson, 1997) related to sedentary life habit restricted to hard substrata and inability of reorientation (LaBarbera, 1978). Similarly, deep-subtidal populations of Terebratulina retusa from Scotland are attached predominantly to Modiolus modiolus (Curry, 1982; Collins, 1991). 

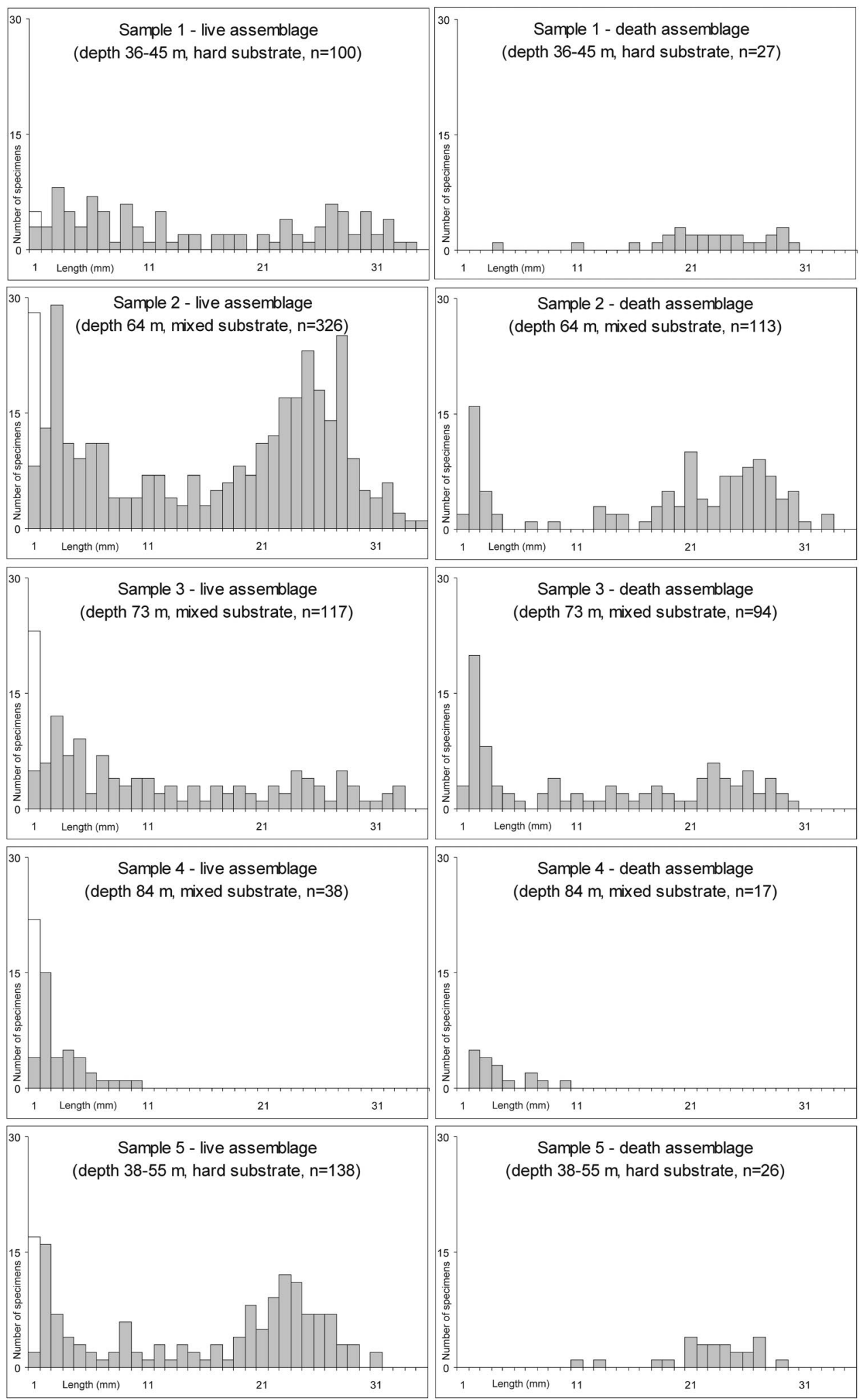

FIGURE 3-Comparison of size-frequency distributions of life and death assemblages from relatively shallow, hard-bottom settings (Samples 1 and 5) and relatively deep, mixed-bottom settings (Samples 2, 3, and 4). White bars in life assemblages represent specimens $<0.9 \mathrm{~mm}$, which were not included in statistical comparisons. 
TABLE 2-Comparison of distributions in terms of their standard parametric descriptors.

\begin{tabular}{|c|c|c|c|c|c|c|c|c|c|}
\hline Sample & $\begin{array}{l}\text { Live/ } \\
\text { dead }\end{array}$ & $\mathrm{n}$ & $\begin{array}{l}\text { Mean } \\
(\mathrm{mm})\end{array}$ & $\begin{array}{c}\text { Standard } \\
\text { deviation } \\
(\mathrm{mm})\end{array}$ & Skewness & Kurtosis & $\begin{array}{c}\text { Maximum } \\
\text { value } \\
(\mathrm{mm})\end{array}$ & $\begin{array}{l}\text { Median } \\
\quad(\mathrm{mm})\end{array}$ & $\begin{array}{c}\text { Range } \\
(\mathrm{mm})\end{array}$ \\
\hline 1 & $\mathrm{~L}$ & 100 & 15.6 & 0.23 & 0.23 & -1.496 & 33.6 & 12.8 & 32.6 \\
\hline 1 & $\mathrm{D}$ & 27 & 22.2 & -1.334 & -1.334 & 2.871 & 29.7 & 22.5 & 26 \\
\hline 2 & $\mathrm{~L}$ & 326 & 17.3 & -0.308 & -0.308 & -1.402 & 34.8 & 21 & 33.7 \\
\hline 2 & $\mathrm{D}$ & 113 & 18.7 & -0.727 & -0.727 & -0.92 & 33 & 22 & 31.7 \\
\hline 3 & $\mathrm{~L}$ & 117 & 13.3 & 0.482 & 0.482 & -1.188 & 33.3 & 10 & 32.1 \\
\hline 3 & $\mathrm{D}$ & 94 & 13.2 & 0.165 & 0.165 & -1.601 & 29.6 & 12.2 & 28.2 \\
\hline 4 & $\mathrm{~L}$ & 38 & 3.6 & 1.431 & 1.431 & 1.774 & 10.3 & 2.6 & 9.1 \\
\hline 4 & $\mathrm{D}$ & 17 & 4.1 & 1.161 & 1.161 & 0.349 & 9.9 & 3.4 & 8.3 \\
\hline 5 & $\mathrm{~L}$ & 138 & 16.3 & -0.427 & -0.427 & -1.34 & 29.7 & 20.1 & 30 \\
\hline 5 & $\bar{D}$ & 26 & 22.7 & -1.202 & -1.202 & 1.855 & 29.1 & 23.3 & 17.9 \\
\hline
\end{tabular}

\section{BETWEEN-SETTING VARIATION OF DEATH} ASSEMBLAGES

\section{Results}

In terms of standard parametric descriptors, comparisons (Table 2) indicate an important difference in the shape of SFDs of Samples 1 and 5 (derived from hard-bottom settings) compared to Samples 2, 3, and 4 (derived from mixed-bottom settings). SFDs of death assemblages from the former setting (Sample 1 and 5) are leptokurtic, left-skewed, and unimodal, in contrast to the SFDs of death assemblages from the latter setting (Samples 2-4), which are platykurtic (with the exception of Sample 4), contain small specimens, and still exhibit signs of polymodality (Fig. 3). Multisample comparisons (Table 4) reveal that SFDs of Samples 1 and 5 are significantly different from SFDs of Samples 3 and 4 . Between samples from mixed-bottom settings, Sample 4 is significantly different from Sample 2.

\section{Discussion}

Significant differences between the SFDs of death assemblages of Samples 1 and 5 (shallow, hard-bottom settings) and Samples 2, 3, and 4 (deeper, mixed-bottom settings) indicate that the primary distinction in taphonomic pathways is related to environmental differences between these two settings, which probably is related to several interrelated variables, including the substrate type, waterenergy level, and/or net rate of sedimentation.

\section{LIFE AND DEATH ASSEMBLAGES}

\section{Fidelity}

Two theoretical constraints limit direct comparison of size-frequency distributions of life and death assemblages.

Theoretical Constraint 1: The transition from the life to the death assemblage, without any taphonomic loss, depends on several population-dynamic variables, mainly seasonal cessations of growth, and size-selectivity of mortality, along with their seasonal variations (Craig and Oertel, 1966). In life assemblages, age structure of living individuals is directly observed. In contrast, age at death is recorded in death assemblages. This means that any SFD is different in meaning in life and death assemblages (Krebs, 2001). In other words, when SFDs of a life and death assemblage are different, it does not necessarily mean that fidelity is low and vice versa (Powell et al., 1989).

Craig and Oertel (1966) explicated the basic principles underlying the transition from a life to a death assemblage: (1) polymodality can be preserved in the death assemblage only if there are regular seasonal changes in the growth rate (cessations) and/or seasonal increases in mortality rate; (2) if the mortality rate is size-independent (constant), skewness of the life and death assemblages will be identical; and (3) if mortality rate is size-dependent and does not change in the same sense as the growth rate, the skewness of life and death assemblages may be different.

In order to understand this transition, a detailed understanding of a species' population dynamics (controlled by

TABLE 3-Pairwise comparison of SFD of life assemblages between individual samples. The alpha value for significance is $0.05 / 10=0.005$. $\mathrm{SD}=$ statistical decision.

\begin{tabular}{|c|c|c|c|c|c|c|}
\hline Sample & $\begin{array}{c}\text { Kolmogorov- } \\
\text { Smirnov D }\end{array}$ & $\mathrm{p}$ & $\mathrm{SD}$ & $\begin{array}{c}\text { Wilcox } \\
\text { on Z }\end{array}$ & $\mathrm{p}$ & $\mathrm{SD}$ \\
\hline 1 vs. 5 & 0.167 & 0.0759 & Not rejected & 0.04 & 0.968 & Not rejected \\
\hline 1 vs. 2 & 0.163 & 0.0334 & Not rejected & 0.923 & 0.3558 & Not rejected \\
\hline 1 vs. 3 & 0.127 & 0.3437 & Not rejected & 1.647 & 0.0995 & Not rejected \\
\hline 1 vs. 4 & 0.638 & 0.0001 & Rejected & 6.663 & 0.0001 & Rejected \\
\hline 5 vs. 2 & 0.134 & 0.059 & Not rejected & 1.55 & 0.1211 & Not rejected \\
\hline 5 vs. 3 & 0.239 & 0.0014 & Rejected & 2.06 & 0.0393 & Not rejected \\
\hline 5 vs. 4 & 0.693 & 0.0001 & Rejected & 6.691 & 0.0001 & Rejected \\
\hline 2 vs. 3 & 0.228 & 0.0002 & Rejected & 3.302 & 0.001 & Rejected \\
\hline 2 vs. 4 & 0.684 & 0.0001 & Rejected & 7.561 & 0.0001 & Rejected \\
\hline 3 vs. 4 & 0.553 & 0.0001 & Rejected & 6.048 & 0.0001 & Rejected \\
\hline
\end{tabular}


TABLE 4-Pairwise comparison of SFDs of death assemblages between individual samples. The $p$ value for significance is $0.05 / 10=0.005$. $\mathrm{SD}=$ statistical decision.

\begin{tabular}{|c|c|c|c|c|c|c|}
\hline Sample & $\begin{array}{l}\text { Kolmogorov- } \\
\text { Smirnov D }\end{array}$ & $\mathrm{p}$ & $\mathrm{SD}$ & $\begin{array}{c}\text { Wilcoxon } \\
\text { Z }\end{array}$ & $\mathrm{p}$ & $\mathrm{SD}$ \\
\hline 1 vs. 5 & 0.183 & 0.7624 & Not rejected & 0.204 & 0.8379 & Not rejected \\
\hline 1 vs. 2 & 0.226 & 0.2122 & Not rejected & 1.117 & 0.264 & Not rejected \\
\hline 1 vs. 3 & 0.5 & 0.0001 & Rejected & 3.962 & 0.0001 & Rejected \\
\hline 1 vs. 4 & 0.962 & 0.0001 & Rejected & 5.351 & 0.0001 & Rejected \\
\hline 5 vs. 2 & 0.265 & 0.1024 & Not rejected & 1.061 & 0.2885 & Not rejected \\
\hline 5 vs. 3 & 0.522 & 0.0001 & Rejected & 4.026 & 0.0001 & Rejected \\
\hline 5 vs. 4 & 1 & 0.0001 & Rejected & 5.478 & 0.0001 & Rejected \\
\hline 2 vs. 3 & 0.3 & 0.0002 & Rejected & 3.962 & 0.0003 & Rejected \\
\hline 2 vs. 4 & 0.761 & 0.0001 & Rejected & 4.24 & 0.0001 & Rejected \\
\hline 3 vs. 4 & 0.542 & 0.0004 & Rejected & 2.755 & 0.0059 & Not rejected \\
\hline
\end{tabular}

the recruitment strategy, overall growth rate and its variations within and between individuals, and size- and timespecificity of mortality rate) can be helpful. Although precise data are not available about the population dynamics of T. transversa, notably whether mortality is high in juvenile stages or is size-independent, and also on the character of seasonal variations in growth rate, direct comparison of the SFDs of life and death assemblages still can be highly informative and useful, bearing in mind what is known about this population structure.

Terebratalia transversa populations in the Pacific Northwest spawn seasonally, probably from November through February (Long, 1964), although episodicity of spawning can be much more irregular, at least in intertidal settings of British Columbia (Thayer, 1977). Due to good water exchange with the Pacific Ocean and high intensity of tidal currents around the San Juan Islands, water temperatures are relatively stable (between 7 and $13^{\circ} \mathrm{C}$ ) in subtidal habitats throughout the year (Thomson, 1981). A biannual spawning pattern typical of some temperate-latitude brachiopods (Curry, 1982, 1984) has not been observed in T. transversa. Growth rate of T. transversa gradually decreases with age and growth may stop in adults. This had been confirmed in T. transversa from direct observations of growth rates (Thayer, 1977) and SFDs and survivorship curves (Long, 1964; Paine, 1969; Thayer, $1975,1977)$. Superimposed on this primary pattern, Buening and Carlson (1992) revealed the presence of relatively short and regular periods of increased growth rate as a response to annual productivity events. Growth rate is known to be highly variable between individuals both within and between habitats (Paine, 1969; Thayer 1977). For example, for the 1976 1-year class, size varied between 2.2 and $10.5 \mathrm{~mm}$ (Thayer, 1977). The mean growth rate for individuals below $10 \mathrm{~mm}$ was $3.4-3.8 \mathrm{~mm} /$ year and for individuals $10 \mathrm{~mm}$ or more in length, it was $1.4-1.7 \mathrm{~mm} /$ year. Mortality rate (assessed for individuals larger than 1 $\mathrm{mm}$ ) was size-independent in the intertidal habitat of Saltspring Island, British Columbia (Thayer, 1977). Thus, it is reasonable to infer that episodic recruitment, longterm decrease in growth rate, and short-term seasonal variations in growth rate should be exhibited by subtidal life assemblages of T. transversa from the San Juan Archipelago.

In this case, a polymodal pattern of SFD of the life assemblage, reflecting episodic recruitment, should be preserved in the death assemblage due to seasonal variations of growth rate (Craig and Oertel, 1966, see above). The merging of larger size-groups due to slowing or cessation of growth in the adult stage probably produces the secondary (right-hand) peak (Craig and Hallam, 1963). If the mortality rate is constant (as revealed in intertidal populations) or decreasing (higher juvenile mortality), the death assemblage should be right-skewed, as in the life assemblage.

Theoretical Constraint 2: Time-averaging of the death assemblage lying on the seafloor mixes multiple generations, in contrast to the snapshot presented by the life assemblage. The effect of time-averaging on SFD is complex because both causal factors (population dynamics and extrinsic taphonomic processes) can be inconsistent over time, which partly depends on the scale of observation (i.e., whether long-term or short-term patterns of population dynamics are addressed). A fixed size-frequency distribution is possible under stable age distribution (constant birth and death rate leading to geometric increase of population size) or stationary age distribution (birth rate equals death rate leading to a constant population size). In natural populations, fixed-age distributions are rare because populations do not increase in size infinitely and are rarely in a stationary phase for long (Krebs, 2001). Indeed, it is known that short-term population dynamics of brachiopods may exhibit marked fluctuations throughout the year due to variations in recruitment, growth rate, and mortality (James et al., 1992). This can lead to the fact that in each month, the SFD of brachiopod life assemblage is different (Doherty, 1979).

If the death assemblage is formed by gradual accumulation of successive, non-contemporaneous populations of preservable organisms over time (i.e., time-averaged; Walker and Bambach, 1971), its SFD will represent a cumulative SFD composed of many originally distinct cohorts. In this case, short-term fluctuations will be attenuated. The ideal size-frequency distribution of the death assemblage could be approximated as the result of continuous (all units of time equally represented; cf., Fürsich and Aberhan, 1990) and non-size-selective time-averaging, without any loss of dead individuals. One approach to assess the fidelity of SFDs of life and death assemblages should thus be the construction of an ideal SFD of the death assemblage with input of data from population dynamics and some absolute value of time-averaging, followed by comparison with the real SFD of the death assemblage. With exception of the increase in mortality rate 
TABLE 5-Pairwise comparison of SFDs of life and death assemblages within individual samples using Kolmogorov-Smirnov and Wilcoxon two-sample tests. The $p$ value for significance is $0.05 / 5=0.01$. SD $=$ statistical decision.

\begin{tabular}{ccclcll}
\hline \hline Sample & $\begin{array}{c}\text { Kolmogorov- } \\
\text { Smirnov D }\end{array}$ & \multicolumn{1}{c}{ p } & \multicolumn{1}{c}{ Wilcoxon } & \multicolumn{1}{c}{ Z } & SD \\
\hline 1 & 0.478 & 0.0001 & Rejected & 2.643 & 0.0082 & Rejected \\
2 & 0.129 & 0.1216 & Not rejected & 0.904 & 0.365 & Not rejected \\
3 & 0.156 & 0.154 & Not rejected & 0.652 & 0.515 & Not rejected \\
4 & 0.244 & 0.483 & Not rejected & 1.047 & 0.2949 & Not rejected \\
5 & 0.367 & 0.0054 & Rejected & 3.027 & 0.0025 & Rejected \\
\hline
\end{tabular}

(i.e., low juvenile mortality), it thus would be possible to directly compare the SFDs of life and death assemblages, and the difference between the observed death assemblage and the assemblage predicted from theory should be inversely proportional to the degree of fidelity. However, because continuous sampling of the life-assemblage population structure for long times is necessary for such a purpose, this approach is difficult to apply at this time.

The other, perhaps more simple approach is to compare SFDs of life and death assemblages based on the assumption that, if the population dynamics of a given species vary through time (i.e., if there is differential production of dead shells), and different size classes have different postmortem durabilities, the SFD of the time-averaged death assemblage should not mirror the SFD of a snapshot life assemblage (see Kidwell, 2002, for an analogous assumption when comparing rank-order abundances). Hence, when SFDs are similar, either population dynamics were stable/stationary through time and differences in durabilities were small, or time-averaging was limited to the most recent cohorts, or the similarity is the result of chance only. Because it is possible to determine the relative degree of time-averaging from independent taphonomic data, the effect of time averaging on SFD patterns will be evaluated $a$ posteriori (see below).

\section{Results}

In spite of the theoretical constraints (see above), direct comparisons of snapshot SFDs of life assemblages and the time-averaged SFDs of death assemblages are used here as first approximations of their compositional fidelity. SFDs of life and death assemblages of Samples 1 and 5 differ in standard parametric descriptors such as skewness and kurtosis (Table 2). Life assemblages are relatively symmetric and polymodal, whereas death assemblages are left-skewed and unimodal. The difference in SFDs between life and death assemblages is significant in both sites using Kolmogorov-Smirnov D or Wilcoxon test (Table $5)$. The main distinction is the absence of juveniles and strong under-representation of specimens smaller than 15 $\mathrm{mm}$. The maximum abundance of adult specimens (peaks in life assemblage) is not reflected in SFDs of death assemblages. In both samples, absolute abundance of individuals is much lower in the death assemblage.

In Samples 2-4, the pattern of SFD of death assemblages is different. Samples 3 and 4 are typified by relatively high abundance of individuals and a polymodal (with superimposed bimodality) SFD in life assemblages. Platykurtic shape, kurtosis, and skewness are comparable in death assemblages to those in life assemblages, and juve- nile and subadult specimens are not under-represented. The bimodality with several superimposed smaller, distinct modes, which are characteristic of the life SFDs are still preserved in death assemblages in Samples 2 and 3. In spite of a relatively low number of individuals, SFDs of life and death assemblages of Sample 4 are very similar, both being right-skewed and leptokurtic. Absolute abundance of specimens always is smaller in death assemblages, although the difference in Sample 3 is relatively small. Pairwise comparison tests of life and death assemblages in all three samples found no significant differences.

\section{Discussion}

Comparative analysis of SFDs of life and death assemblages of brachiopod populations indicated that there is variation in the fidelity of hard-bottom and mixed-bottom habitats (Fig. 4).

(1) In shallow, subtidal, hard-bottom settings with pebbles and cobbles (Samples 1 and 5), parameters such as skewness, kurtosis, and modality characterizing SFD of the T. transversa life assemblages are not preserved in the SFD of the death assemblages. However, a less pronounced bi- and/or multimodality may be related to much smaller sample size in the death assemblages. Several interrelated factors can enhance the rate of taphonomic destruction in hard-bottom settings. Low net rate of sedimentation leads to long residence time on the sea floor (no sediment available to bury the shells). Higher intensity of long-term or episodic, high water energy leads to increased mechanical reworking, winnowing, exhumation/ burial cycles, and/or hard substrata, which are more heavily attacked by bioeroders. In addition, stronger irrigation of pore waters provides a greater potential for carbonate dissolution and microbial attack.

Because the finer siliciclastic fraction is lacking in Samples 1 and 5, the most parsimonious assumption for exclusion of juveniles would be winnowing and/or mechanical destruction. Similar results from hard-bottom settings also have been obtained by other authors. In gravel deposits of New Zealand, Lee (1978) noted the absence of juvenile specimens in dredged death assemblages of Notosaria nigricans, and attributed this to selective destruction due to reworking and winnowing. The SFD of the death assemblage of Terebratulina septentrionalis from semi-cryptic, subtidal rock-wall habitats in the Gulf of Maine was significantly different from the bimodal SFD of the life assemblage (Kolmogorov-Smirnov test, $\mathrm{p}<0.01$ ), primarily due to the absence of juvenile specimens (Witman and Cooper, 1983). Slightly different results were reported by Stewart (1981) for the shallow, subtidal hard-bottom hab- 


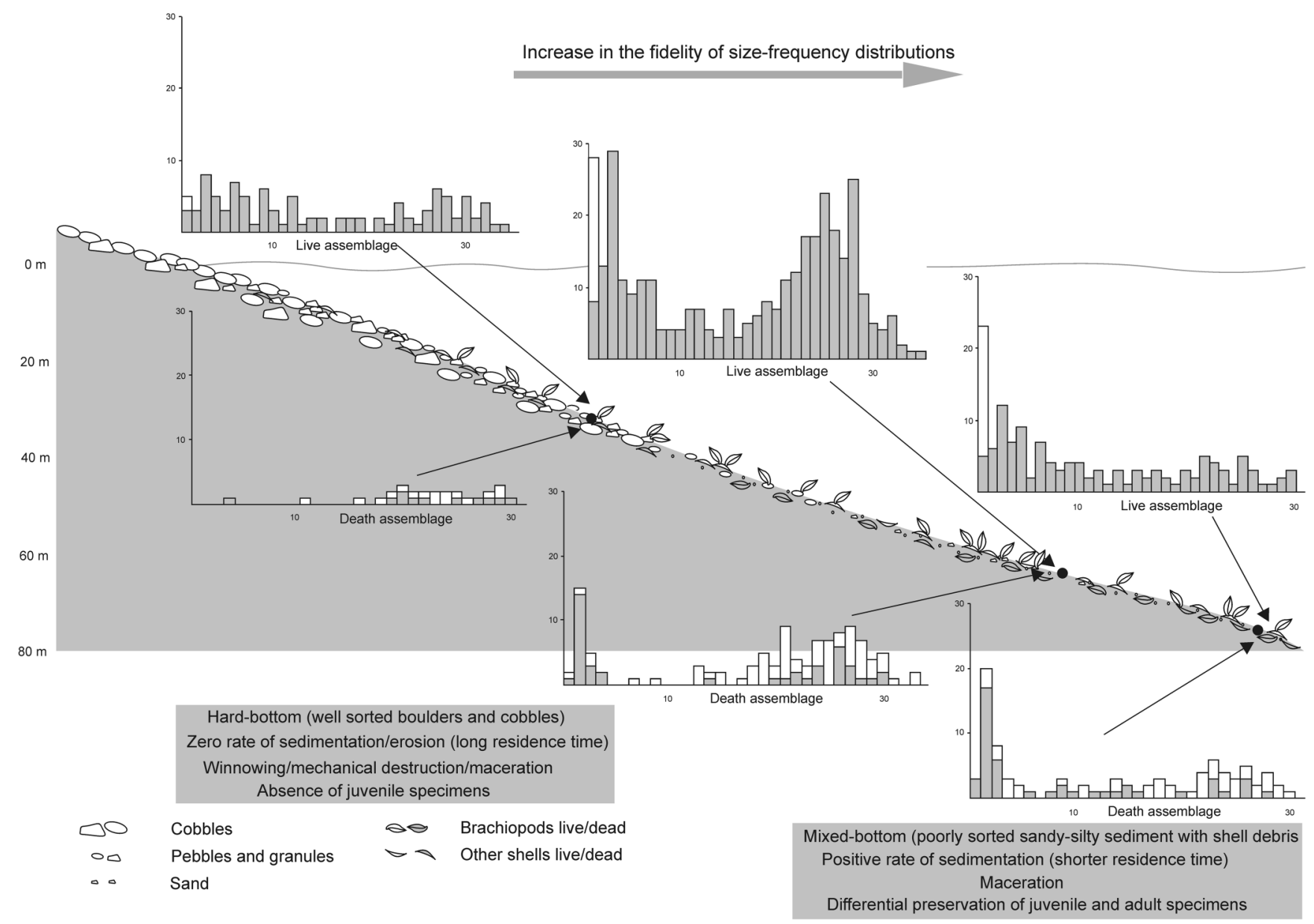

FIGURE 4-Schematic relationship of SFDs of life and death assemblages of Terebratalia transversa and their fidelity with respect to a simplified bathymetric gradient and inter-related environmental factors (substrate, rate of sedimentation). In life assemblage, white bars represent specimens $<0.9 \mathrm{~mm}$. In death assemblages, white parts of bars represent specimens affected by internal surface alteration, gray parts represent specimens unaffected by internal surface alteration.

itats of Stewart Island (New Zealand). SFDs of life and death assemblages from a shallow, subtidal hard-bottom setting were characterized by relatively high fidelity with respect to their left-skewness and polymodality. However, specimens smaller than $2 \mathrm{~mm}$ were lacking in the death assemblages. Tunnicliffe and Wilson (1988) studied the SFD of Laqueus californianus assemblages from deep, subtidal hard-bottom habitats in fjords of British Columbia, Canada. The death assemblage collected by a box core contained a high proportion of smaller specimens $(3-5 \mathrm{~mm}$ long), and the SFD of the death assemblage was bimodal and comparable to that of the life assemblage. Thus, not all hard-bottom settings suffer from an under-representation of juveniles. Although it is known that preservation potential of high-energy, hard-bottom deposits is mostly low, there are many examples of paleoecologic studies of such deposits (Bryan, 1992; Lee et al., 1997, Aguirre and Jiménez; 1997; Wilson and Taylor, 2001; see reviews in Brett, 1988 and Taylor and Wilson, 2003). For example, Asgaard and Bromley (1991) interpreted the population structure of rhynchonellid brachiopods preserved under large gneiss boulders derived from a very shallow, highenergy environment.

(2) In the mixed-bottom habitats with a higher propor- tion of fine, unconsolidated sediment (Samples 2-4), skewness, modality, and kurtosis with distinct juvenile peaks are relatively well preserved in the SFD of $T$. transversa death assemblages. In such environments, the net rate of sedimentation is usually higher, the probability of burial is higher, the intensity of reworking is lower, and higher turbidity and soft substrata can lead to the exclusion of encrusters and bioeroders (cf., Best and Kidwell, 2000a). Higher preservation potential of such habitats was supported by Kidwell's (2001) analysis of 85 molluscan datasets that revealed that species live-dead rank-order correlations are significantly higher in muddy habitats than in sandy and gravelly habitats.

Noble and Logan (1981) evaluated the taphonomic pathways leading to the formation of the Terebratulina septentrionalis death assemblage in a small cave with rock walls in the shallow-subtidal zone of the Bay of Fundy (New Brunswick, Canada). SFDs of death assemblages from this mixed-bottom setting were very similar to those of life assemblages, characterized by right-skewness and a strong juvenile peak at about $4 \mathrm{~mm}$. However, in subtidal soft-bottom habitats of New Zealand (Stewart, 1981), the SFDs of death assemblages of three terebratulid species were characterized by under-representation of smaller 
specimens. The fidelities of larger specimens were relatively high.

In summary, this discussion and overview of known actualistic comparisons of SFDs of brachiopod life and death assemblages from temperate siliciclastic settings revealed that low-energy habitats with higher proportions of soft substrata are mostly characterized by higher fidelity. It is obvious that variation in environmental (extrinsic) factors is important in controlling the preservation potential of SFD of the death assemblage, but it does not explain all fidelity patterns. Contrasting results from New Zealand (higher fidelity of the death assemblage preserved in shallow, high-energy settings, in contrast to low fidelity in deeper, low-energy settings) suggest that some other, probably intrinsic factors also may be important (see below).

\section{SHELL PRESERVATION AND SIZE-FREQUENCY DISTRIBUTIONS}

\section{Results}

Superimposing the information on internal surface alteration onto the size-frequency histograms makes clear the differential contribution of well- and poorly preserved shells to the size-frequency distributions (Fig. 5). Relative proportions of well- and poorly preserved small and large specimens with respect to internal surface alteration, disarticulation, and fragmentation are illustrated in Figure 6. In order to exclude possible disproportional effects of different numbers of disarticulated valves/articulated shells (taphonomic processes can affect them unequally), both XNI (maximum number of individuals) and MNI (minimum number of individuals) approaches were used to recognize variation in preservation of different size classes. Specimens contributing to the juvenile peak $(<6.5$ $\mathrm{mm}$ ) in death assemblages from Samples 2-4 are in most cases well preserved (73-81.2\% for XNI, 77.8-90.9\% for MNI), with unaltered interior shell surface. In contrast, larger specimens $(>6.5 \mathrm{~mm})$ include a high proportion of shells with internal surface alteration. In Samples 1 and 5 , the proportion of specimens larger than $6.5 \mathrm{~mm}$ with altered interior surfaces reaches $65.4 \%$ and $69.2 \%$ for XNI, and $59.1 \%$ and $69.6 \%$ for MNI, respectively. In Samples 2 and 3 , the proportion is relatively similar to the previous one, reaching $74.4 \%$ and $66.1 \%$ for XNI and $73.1 \%$ and $57.9 \%$ for MNI. If softened shells are removed, abundances of individual size classes are more restricted. The difference between the proportion of altered small and altered large specimens is statistically significant (Fig. 6; MannWhitney $\mathrm{U}$ test, $\mathrm{Z}=-2.121, \mathrm{p}<0.05$ ). In all samples, the proportions of altered adults in samples are relatively similar (65.4-74.7\% for XNI and 57.9-69.6\% for MNI).

With regard to the proportion of articulated shells, the difference in the percentage of disarticulation in small and large specimens is not significant (Fig. 6; Mann-Whitney $\mathrm{U}$ test, $\mathrm{Z}=0.707, \mathrm{p}=0.314$ ). The variation of this taphonomic signature is relatively high in both groups. In specimens smaller than $6.5 \mathrm{~mm}$, the proportion of disarticulated specimens is either higher (78.4\% in Sample 3 and $81.2 \%$ in Sample 4) or lower (46.6\% in Sample 2). Specimens larger than $6.5 \mathrm{~mm}$ are mostly characterized by higher proportion of disarticulated specimens (57.7-
$63.8 \%)$ or the proportion of articulated and disarticulated specimens is equal (50\% in Sample 1). The difference in proportion of fragmented small and large specimens is similarly not statistically significant (Fig. 6; Mann-Whitney $\mathrm{U}$ test, $\mathrm{Z}=-0.353, \mathrm{p}=0.428$ ).

\section{Discussion}

The substantial taphonomic damage observed on the internal surfaces of Terebratalia transversa specimens (jagged secondary layer with loosened fibers) is comparable to shell maceration (Alexandersson, 1979). This term is used to denote the process leading to breakdown of skeletal carbonate due to disintegration of shell structures into their microscopic constituent elements, primarily due to decomposition of organic matter in the shell. Shell maceration in punctate brachiopods is a very common feature in modern temperate siliciclastic regions and it rapidly leads to the total disintegration of the shell (Alexandersson, 1979; Stewart, 1981; Collins, 1986; Emig, 1990). Independent taphonomic data, including experiments of the hinge and valve strength (Daley, 1993), comparison of mechanical properties of live and dead brachiopod shells (LaBarbera, pers. comm., 2003), bioerosion patterns, and small-fraction preservation (Hannisdal, 2004) indicate that punctate brachiopod shells also degrade very rapidly in the San Juan Archipelago. Shell maceration is probably a consequence of the relatively high proportion of organic matter within the shell of punctate brachiopods (0.93-4.73\% dry weight; Jope, 1965; Peck et al., 1987). The proportions of specimens with internal surface alteration are relatively similar in all samples, indicating that the process of alteration is important in both hard-bottom and mixed-bottom settings.

Relatively uniform, good preservation of smaller specimens and the high proportion of internal alteration of larger specimens point to differential preservation and size-selectivity of taphonomic processes. In general, the lower frequencies of taphonomic damage among small or thin specimens are well known in the fossil record (Bosence, 1979; Arua, 1982; Best and Kidwell, 2000b).

Two explanations of the observed differences in internal surface alteration among different size classes are possible: (1) the rate of degradation of organic matter in the shell is higher in larger specimens than in smaller ones. In habitats with soft, unconsolidated sediment, there is a higher probability for rapid burial of smaller specimens due to bioturbation or episodic sediment reworking. Smaller and thinner shells are certainly a less-suitable substrate for boring organisms, known for their highly selective infestation behavior. However, the degree of bioerosion is relatively small also in the adult specimens of Terebratalia transversa (Hendy, pers. comm., 2003). (2) If the rate of degradation of organic matter is the same, smaller shells will have a shorter taphonomic half-life than larger shells. Because of their thin, delicate nature and the higher surface-to-volume ratio, smaller shells will degrade more rapidly than large specimens under the same conditions. Although the relative proportion of organic matter in the shell of punctate brachiopods does not vary with ontogenetic size increase, its mean value is relatively high (e.g., 3.46\% dry weight in Liothyrella uva; Peck et al., 1987). Good preservation of Terebratalia juve- 

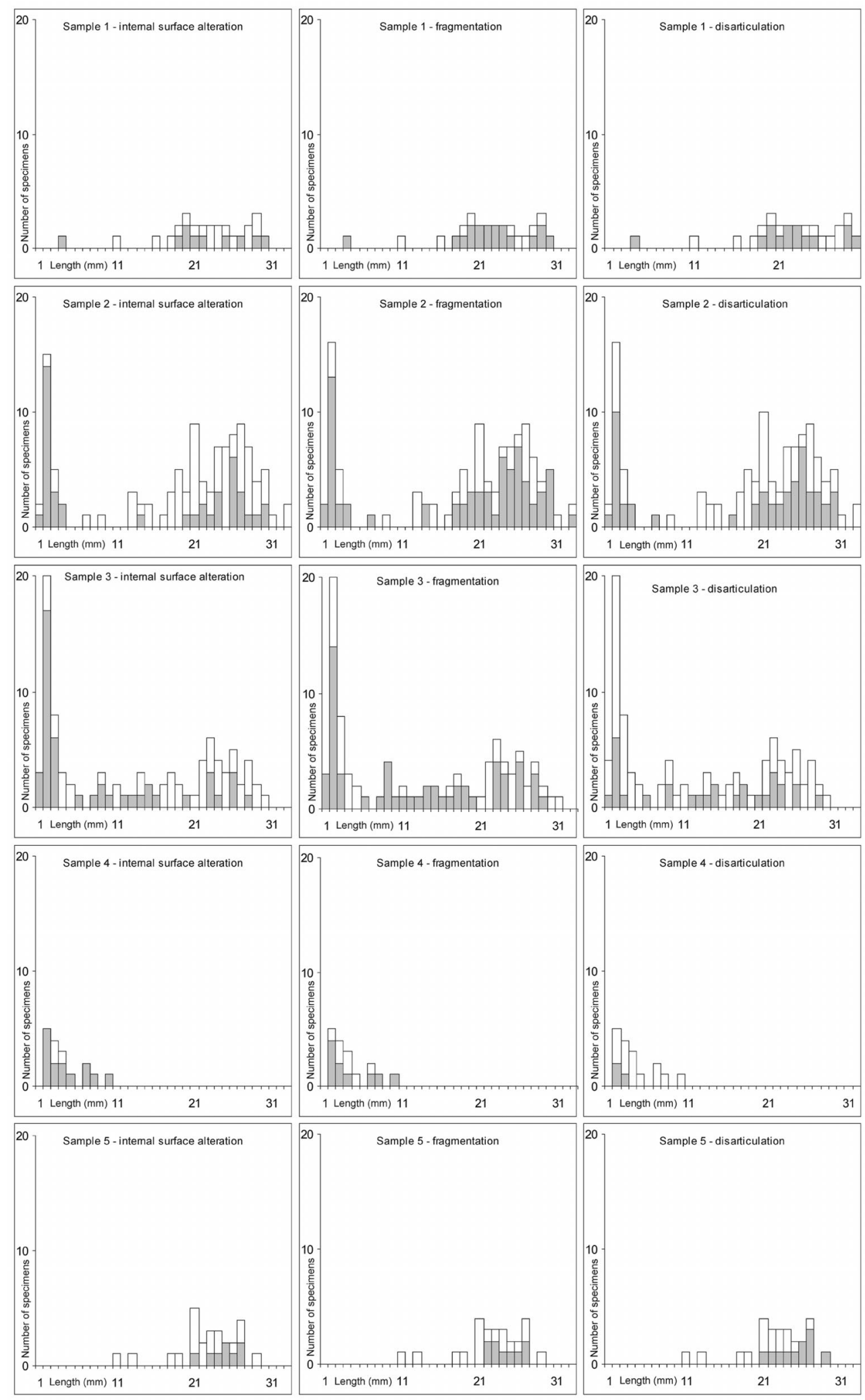

FIGURE 5-The distribution of internal surface alteration (first column), fragmentation (second column), and disarticulation (third column) in SFDs of death assemblages. Gray parts of the bars represent well-preserved specimens; white parts represent poorly preserved specimens. Juvenile specimens in death assemblages mostly are characterized by unaltered internal surfaces. 


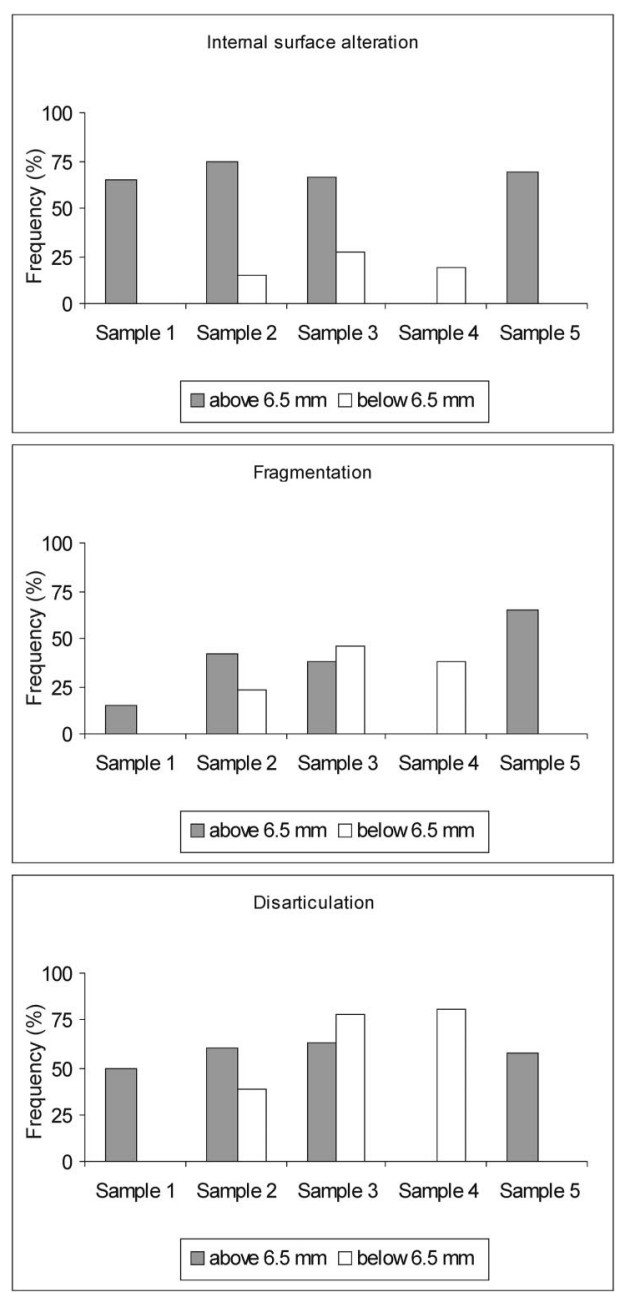

FIGURE 6-Comparison of difference in taphonomic preservation of small and large specimens. The difference in the proportion of internal surface alteration between smaller $(<6.5 \mathrm{~mm})$ and larger specimens is significant (Mann-Whitney $U$ test, $p<0.05$ ).

niles is then only a consequence of their short residence time on the seafloor. Therefore, a high proportion of juvenile or small specimens of Terebratalia probably represents a very recently died cohort. Larger Terebratalia specimens probably represent a longer, time-averaged interval. Size-selective preservation leading to the under-representation of juveniles is typical for death and fossil assemblages (Olson, 1957; Powell et al., 1986; Cummins et al., 1986a, b). As a consequence of this selectivity, different size classes probably are time-averaged to different degrees (disharmonious time-averaging). Kowalewski (1996a) originally proposed the term disharmonious to denote differential time-averaging among different taxa. In this paper, the term is expanded to involve differential time-averaging of any aspect of a fossil assemblage (e.g., age or size class, morphotype, taxon, or guild) over different time scales, depending on the goal of study. Note that due to disharmonious time-averaging of the studied object, its compositional fidelity (i.e., fidelity of the record of morphologies, size/age classes, species richness or abundance, trophic structure, etc. cf., Behrensmeyer et al., 2000) may not be preserved faithfully in a death assem- blage. Therefore, differential postmortem durability as an intrinsic preservation factor has an important influence on the fidelity of the SFD of a death assemblage.

Detailed studies of fidelity of SFDs of bivalve death assemblages and differential preservation of juveniles from the Texas coast provided comparable results (Cummins et al., 1986a), stressing variation in the rate of destruction between individual size classes. In spite of continuous input of juveniles into the death assemblage, the resulting SFD was different from the calculated SFD, which involved living individuals that died during their study period. Comparisons of the SFD of the death assemblage just after addition of a pulse of juveniles and after the pulse had decayed revealed that without high juvenile input, the SFD will not be strongly right-skewed because juveniles degrade very rapidly. Similarly, in brachiopod death assemblages from the San Juan Archipelago, higher rates of destruction of juvenile specimens should lead to the attenuation of their abundance in the death assemblages. Therefore, without production of new juveniles and their transfer to the death assemblage, they will be lost rapidly from the potential fossil assemblage. In spite of this, SFDs of some samples from the San Juan Archipelago are dominated by juvenile brachiopods. This points to the importance of another intrinsic factor in controlling the shape of the SFD of a death assemblage: dead-shell production, which is related to the frequency of input (e.g., constant versus episodic recruitment) and total volume (production) of live juveniles, and their mortality (e.g., constant versus high juvenile mortality and/or continuous versus catastrophic mortality).

Given the data about the high rate of destruction of juveniles, differential postmortem durabilities leading to the disharmonious time-averaging and, assuming probable variations in the population structure (and dead-shell production) on a short-term scale, the high fidelity of the SFDs of the death assemblages from mixed-bottom settings are surprising. In the San Juan Archipelago, life assemblages, despite differential durability of mollusks and brachiopods, are reasonably well represented in the death assemblages in terms of taxonomic composition and rank abundance of dominant taxa (Kowalewski et al., 2003). Interestingly, on the level of community analysis, the high agreement of relative-abundance data in molluscan death assemblages (Kidwell and Flessa, 1996; Kidwell, 2002) is supposed to be caused by the dominance of the most recent dead cohorts. This supports the suggestion that the close correspondence of the SFDs of the death assemblages to the snapshot-like SFDs of the life assemblages in the San Juan Archipelago also is probably the consequence of very limited time-averaging and the snapshot-like character of the death assemblages themselves (i.e., the death assemblages are dominated by brachiopods that died recently). Therefore, intrinsic factors, including variations in deadshell production and differential durability, need to be incorporated in the evaluation of possible factors influencing SFD fidelity indices. In the following section, simple deterministic models are explored in order to visualize a relationship between differential dead-shell production and differential durability. 


\section{RELATIONSHIP BETWEEN DIFFERENTIAL DEAD- SHELL PRODUCTION AND DIFFERENTIAL DURABILITY}

This relationship can be shown in four simple deterministic models illustrating how the original number of juveniles, added into the local death assemblage after deadshell production (in this case dead-shell production following recruitment) will change during the short-term interval of two years (Fig. 7). The goal of these models is to explore the influence of differential postmortem durability and variations in a frequency of dead-shell production on preservation potential of juveniles.

Variation in dead-shell production is related to the frequency of recruitment, and differential postmortem durability is expressed by the taphonomic half-life. The type of mortality (e.g., continuous or catastrophic) is another important variable influencing preservation potential of juveniles, but the variables are chosen primarily to illustrate the basic relationship between the rate of destruction and the rate of dead-shell production. Because the purpose is to show the interplay of intrinsic factors only, extrinsic (environmental) factors are constant in these models. These models do not incorporate effects of the burial rate, probability of reworking, and transport (for exploration of these factors, see Powell, 1992; Cutler, 1993; Miller and Cummins, 1990, 1993; Olszewski, 1999, 2004). The taphonomic half-life is a function of both extrinsic factors and inherent durability, but leaving extrinsic factors constant, the inherent durability will be the direct proxy for taphonomic half-life. Although these deterministic models are hypothetical, they can be used to compare preservation potential of juveniles with different postmortem durabilities and/or differential population dynamics in the same type of environment.

A growth rate of 3-mm-per-6 months is used as the initial growth rate of juvenile brachiopods after settlement (Thayer, 1977; Doherty, 1979). In a simplified situation, assuming no variations in the growth rate, this means that 6 months after recruitment, no live individuals smaller than $3 \mathrm{~mm}$ (derived from this recruitment) will be present in a life assemblage, and therefore cannot be added into the local death assemblage. In order to show the relationship between the recruitment frequency and the taphonomic half-life, the term juvenile is restricted to specimens smaller than $3 \mathrm{~mm}$ in the following text. Detailed data on reproductive cycles of articulate brachiopods are relatively rare (James et al., 1992), but known strategies include single-annual, biannual, multi-annual, and continuous spawning. In these models, the effect of episodic annual and bi-annual spawning types on preservation potential of juveniles is compared. The taphonomic half-life $(\tau)$ measures rate of shell destruction, and is computed with the equation of exponential decay:

$$
\mathrm{N}_{\mathrm{t}}=\mathrm{N}_{0} \mathrm{e}^{-\lambda t}
$$

(Cummins et al., 1986b; Meldahl et al., 1997), where $\mathrm{N}_{\mathrm{t}}$ is the number of preserved dead shells after time $t, \mathrm{~N}_{0}$ is the initial number of dead shells added in each increment of time and $\lambda$ is the rate of taphonomic loss $(\lambda=\ln 2 / \tau)$. The rate of taphonomic loss (coefficient of taphonomic decay) includes all processes that lead to shell destruction (Olszewski, 1999), and in models it is assumed that the prob- ability of shell removal is equal for every juvenile. Two values of the taphonomic half-life are used and compared in the models: 3 months (the taphonomic half-life of bivalve juveniles measured in Texas bays; Cummins et al., 1986b) and 6 months (assumed rate of destruction of adult brachiopods in the Mediterranean Sea; Emig, 1990). In the models, conservative estimation of $75 \%$ mortality rate is used for the first year (Doherty, 1979). For simplification, it is assumed that addition of dead juvenile shells occurs in one-month intervals. As $\mathrm{N}_{0}$ (the function of mortality rate) and $\Delta t$ (the function of the recruitment frequency and the frequency of inputs of dead shells) are not constant, the equation:

$$
\begin{aligned}
\mathrm{N}(\mathrm{T})= & \mathrm{N}_{0} \mathrm{e}^{-\lambda \mathrm{T}}+\mathrm{N}(\Delta \mathrm{t}) \mathrm{e}^{-\lambda(\mathrm{T}-\Delta \mathrm{t})}+\mathrm{N}(2 \Delta \mathrm{t}) \mathrm{e}^{-\lambda(\mathrm{T}-2 \Delta \mathrm{t})}+\ldots \\
& +\mathrm{N}(\mathrm{n} \Delta \mathrm{t}) \mathrm{e}^{-\lambda(\mathrm{T}-\mathrm{n} \Delta \mathrm{t})}
\end{aligned}
$$

was used for computation of multiple inputs of dead juveniles in the local death assemblage (Martin, 1999), where $\mathrm{N}(\mathrm{T})$ is the number of preserved dead juveniles at total time $\mathrm{T}(\Sigma \Delta \mathrm{t}), \mathrm{N}(\mathrm{n} \Delta \mathrm{t})$ is the number of dead juvenile shells added at time T-n $\Delta$ t, intervals $\Delta$ t correspond to a time between inputs of dead shells, and $\mathrm{n}$ is the number of deadshell inputs in the death assemblage. The ratio of the preserved dead juveniles after time $t\left(\mathrm{~N}_{\mathrm{t}}\right)$ to the original number of dead shells after one input at the beginning of time $\mathrm{t}\left(\mathrm{N}_{0}\right)$ defines the unit impulse (input) response $\mathrm{H}_{\mathrm{t}}(\mathrm{Mar}-$ tin, 1999):

$$
\mathrm{N}_{\mathrm{t}} / \mathrm{N}_{0}=\mathrm{H}_{\mathrm{t}} \text {. }
$$

The number of new recruits is schematically determined as 1000 for each recruitment. Six months after recruitment, 600 dead juveniles have been added into the death assemblage. There is constant addition of 600 dead juveniles into the death assemblages after each recruitment. Thus, the unit impulse response $\left(\mathrm{H}_{\mathrm{t}}\right)$ corresponds to the percentage of dead juveniles $\left(100 \mathrm{H}_{t}\right)$ that potentially can be preserved with respect to the original number of produced dead juveniles $\left(\mathrm{N}_{0}=600\right)$.

In the models, the absolute abundance of potentially preservable juveniles exponentially decreases after recruitment, until new recruitment occurs. When the number of juveniles declines below one in the tail of the exponential distribution, no juveniles will be preserved in the local death assemblage.

\section{Annual Model}

In a model with annual recruitment, after 6 months there is no input of new dead juveniles into the local death assemblage (Fig. 7A-B). With a 3-month-long taphonomic half-life, $51 \%$ of juveniles are preserved after 6 months and only $12 \%$ after 12 months (Fig. 7A). Between months 6 and 12, the abundance of preservable dead juveniles will form only $12-51 \%$ of their original number. The relative abundance of individual size classes in the predicted SFDs is strongly biased (Fig. 7A). If there is a failure in recruitment in the next year, no dead juveniles will be preserved after 24 months. Due to this short half-life, time-averaging of non-contemporaneous juveniles does not take place. With a 6-month-long half-life (Fig. 7B), the abundance of preservable juveniles is slightly higher, although still highly under-represented after 12 months (34\%). In this 

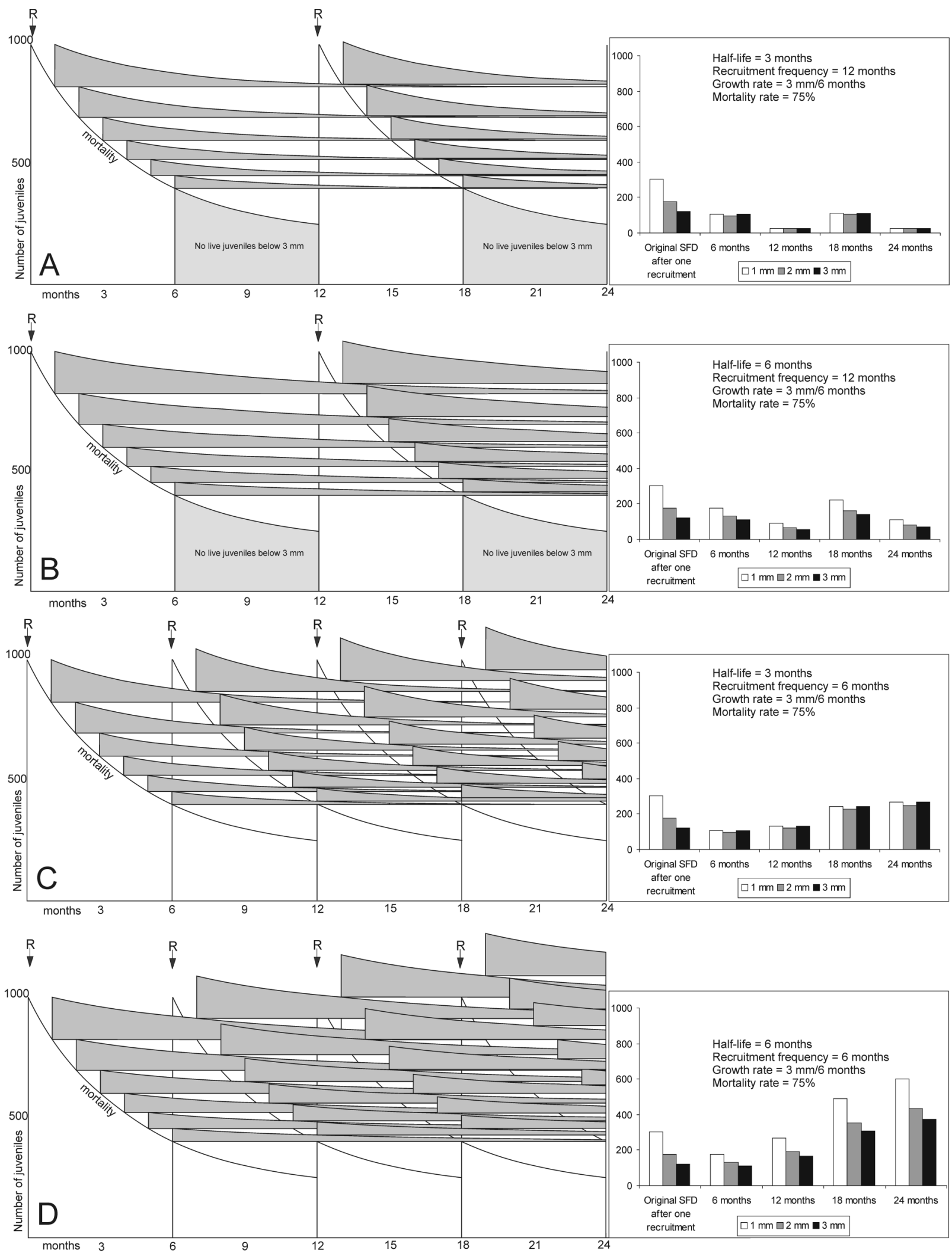

FIGURE 7-Four models illustrating the relationship between the frequency of dead-shell production (in this example, the frequency of recruitment $=\mathrm{R}$ ) and the rate of shell destruction (taphonomic half-life) of juveniles. On the left side, the exponential decay of successive cohorts of dead juvenile shells is shown on the scale of 2 years. On the right side, the predicted SFDs of dead juvenile shells at the 6th, 12th, 18th, and 24th month intervals are compared with the original SFD of dead juveniles produced after one recruitment. For simplification, addition of dead juveniles in the local death assemblage is stepwise (in one-month intervals). In all models, the growth rate of juveniles is 3-mm/6-months and the mortality rate is $75 \%$ per 1 year. (A) Single, annual recruitment and a 3-month-long taphonomic half-life. (B) Single, annual recruitment 
case, the relative abundance of individual size classes in the predicted SFDs is well preserved in the local death assemblages (Fig. 7B).

\section{Biannual Model}

New recruitment takes place every 6 months in the biannual model; therefore, in any period of the year, there is a steady input of dead juveniles into the local death assemblage (Fig. 7C-D). With a 3-month-long half-life (Fig. 7C), the lowest value of the abundance of preservable dead juveniles (before next recruitment) stabilizes after 18 months at $67 \%$. However, the relative abundance of size classes in the predicted SFDs is strongly biased towards larger specimens (Fig. 7C). With a 6 month long half-life (Fig. 7D), after 12 months the abundance of preservable dead juveniles reaches $104 \%$ of their original number. After 24 months, there is an overrepresentation of potentially preservable juveniles with respect to juvenile input after one recruitment due to time-averaging of non-contemporaneous juveniles. The relative abundance of size classes in the predicted SFDs is relatively well preserved in the local death assemblages, although with increasing time, there is an increasing bias towards larger specimens (Fig. 7D).

\section{Discussion}

On such a short time scale, relatively subtle differences in the taphonomic half-life and the frequency of recruitment (and related frequency of dead-shell production) can lead to quite different probabilities of preservation of juveniles in the local death assemblage, even with the same mortality and growth rate. If the taphonomic half-life is substantially shorter than the time between inputs of dead shell, the absolute and relative abundance of juveniles will be strongly biased. This relationship between the population dynamics and the rate of shell destruction can explain situations in which even under relatively suitable taphonomic conditions (e.g., low-energy/soft-substrate habitats), juveniles can be absent in death assemblages because of the higher rate of their destruction in comparison to the frequency of production of dead juveniles. For preservation potential of adults, longevity may be an important factor influencing a relationship between the dead-shell input frequency and the taphonomic halflife. The important point is that any interpretation of fidelity of the SFDs of death assemblages needs to be based on the understanding of differential postmortem durability and population dynamics (related to dead-shell production) of the investigated taxa.

As was mentioned above, the population dynamics of brachiopods can vary substantially on the short-term scale. The proportion of juveniles in SFDs of life assemblages is an especially volatile factor on the scale of several months (Thayer, 1977; Doherty, 1979). In contrast, size modes of adults can be relatively stable over several years (Rokop, 1977; Doherty, 1979).
With the exception of the inarticulate brachiopod Neocrania anomala (Taddei Ruggiero, 2001), data on the longterm population dynamics of modern brachiopods on the scale of several years are missing. In other marine invertebrates, there can be substantial variation in the population structure both on the short-term and long-term scale, often related to the opportunistic life strategy (Shimoyama, 1985; Tanabe and Arimura, 1987; Colgan, 1987). In the fossil record, substantial variation in population sizes of invertebrates is inferred mostly from mass-mortality events (e.g., Peterson, 1985; Noe-Nygaard et al., 1987; Farinati et al., 1992). In order to understand dead-shell inputs more explicitly and clearly, the need for long-term examination of population dynamics of brachiopods or other invertebrates is emphasized here.

It is interesting to note that the interplay between the inherent rate of destruction and the frequency of deadshell inputs can be generalized beyond the scale of juvenile shells. It should be important in any situation where differential post-mortem durability and/or differential population dynamics can be expected. For example, this relationship could be tested in death assemblages with taxa characterized by differential postmortem durability (e.g., massive versus branching corals; Pandolfi and Greenstein, 1997a; massive versus encrusting vs. branching bryozoans; Smith and Nelson, 2003). Disproportionate results of fidelity studies of modern coral assemblages (Pandolfi and Minchin, 1995; Greenstein and Pandolfi, 1997; Pandolfi and Greenstein, 1997b; Edinger et al., 2001) indicate that differential postmortem durability, growth rates, and longevity play important roles in understanding of taphonomic processes.

\section{IMPLICATIONS FOR THE FOSSIL RECORD}

\section{Absence of Juvenile Brachiopods in Death Assemblages}

Differences in SFDs of individual brachiopod taxa have been interpreted in terms of their population dynamics (Surlyk, 1972, 1974; Richards and Bambach, 1975; Alexander, 1977; Alvarez, 1986; Cate and Evans, 1992; Bitner, 2002). When factors such as collection failure, transport, mechanical destruction, or dissolution have been excluded and two taxa exhibit quite different proportions of juveniles in one taphofacies type, it is usually concluded that these taxa were characterized by different mortality patterns. It is important to stress that variation in rate of destruction has not been considered as a possible factor in interpretation of SFDs, since the presence of well-preserved juveniles and adults should indicate insignificant taphonomic destruction. In other words, low taphonomic damage of juveniles and adults has been used primarily as evidence that the death assemblages were unmodified by mechanical or biological destruction or transport (Surlyk, 1972; Richards and Bambach, 1975; Olszewski and West, 1997; Bitner, 2002). In the light of actualistic taphonomic observations, the reverse can also be true. Because of the high destruction rate, excellent preservation can occur when specimens that

\section{$\leftarrow$}

and a 6-month-long taphonomic half-life. (C) Biannual recruitment and a 3-month-long taphonomic half-life. (D) Biannual recruitment and a 6month-long taphonomic half-life. 
were exposed only briefly to destructive agents (e.g., specimens that underwent rapid removal from the taphonomic active zone) are exclusively preserved.

When this kind of taphonomic bias with respect to the proportion of juveniles has been excluded, species with reduced or absent juveniles supposedly indicate low juvenile mortality. Cadée (1982a,b) criticized any possibility of low juvenile mortality in brachiopods, and provided two possible explanations: (1) spatial separation of juveniles and adults due to the change from an attached to a free life style; and (2) mass-mortality events that took place a long time after last recruitment, when only adults were present in the life assemblage. In regard to the first argument, it is hard to suppose that adults could be moved too far from their position as juveniles. In regard to the second argument, it can be argued that even when census assemblages are preserved by rapid burial (regardless of the time passed since last recruitment), there still should be some juveniles that died before the mass-mortality event. However, it is important to take into account the possibility that even when the juveniles are well preserved, significant bias still can be present due to differences in postmortem durability. Cadée's (1982a,b) relationship between the timing and frequency of recruitment and the burial period (or escape from the taphonomically active zone) plays an important role in preservation potential of juveniles, and it also interplays with the rate of destruction. This statement is trivial, but as shown in deterministic models (see above), when the inherent rate of destruction of juveniles occurs on a scale of a few months, there will be marked short-term fluctuations of juvenile numbers in the local death assemblage because of short-term fluctuations in their population dynamics. After recruitment, with continuing time, the probability of adding new juveniles to the death assemblage decreases because juveniles grow relatively rapidly. Therefore, the maximum input of dead juveniles will most probably take place shortly after recruitment (even if the mortality rate is size-independent). If the taphonomic half-life of juveniles is shorter than the time between recruitments, when the sampling of the death assemblage takes place after destruction of substantial number of juveniles (that died after the recruitment) and before the next recruitment (followed by new dead-shell production), the absolute abundance of juveniles will be under-represented in this death assemblage. Consequently, the final proportion of juveniles in death assemblages will be substantially interrelated to the period at which their incorporation took place.

Therefore, in brachiopods characterized by multi-annual or continuous spawning, the preservation potential of juveniles will be higher in comparison to brachiopods with single, annual spawning events. Known data about supposed rate of destruction of brachiopods in temperate siliciclastic settings indicate that punctate brachiopods may disappear within several months (Collins, 1986; Emig, 1990). This rate can be sufficient to remove a high amount of the juveniles from the death assemblage, whose time span between inputs of new dead shells significantly exceeds the period during which most juveniles are degraded.

\section{Application of Size-Frequency Distribution}

SFDs of death assemblages provide a highly informative tool for understanding taphonomic pathways leading from life to death assemblages, including a high-resolution proxy not only for the magnitude of these processes, but also for estimation of variation and selectivity of taphonomic destruction (Cummins et al., 1986a). The intensity of taphonomic destruction in individual size classes allows recognition of differential preservation of juveniles versus adults. Disparate postmortem durabilities of small and large specimens prove to have high potential for recognition of the degree of compositional fidelity and disharmonious time-averaging. Size-selectivity of taphonomic destruction then can be used not only for assessment of differential durability in species-level analysis, but also for different hierarchic levels of higher taxa with comparable intrinsic shell properties (e.g., pectinid bivalves or punctate brachiopods).

Differences between death assemblages derived from different bathymetric settings prove that SFDs reflect some aspects of (paleo)environments, mainly related to the substrate type, water energy level, and/or rate of sedimentation. Deeper settings with higher proportions of soft substrata appear to have a higher potential to preserve the original SFD of the life assemblage.

From the point of view of population ecology, it is important to note that between-habitat variations in SFDs of life assemblages can be preserved in SFDs of death assemblages. However, relatively good agreement in compositional fidelity is probably also the effect of limited time-averaging of frequency distribution of individual size-classes. Time-averaging is considered to be the factor that makes any interpretation of short-term population dynamics impossible (Miller and Du Bar, 1988). In the case when the scale of temporal mixing exceeds the time scale of population dynamics, several, in some cases unreliable, assumptions (e.g., constant population dynamics, constant environmental conditions, and harmonious time-averaging) are necessary for interpretation of SFDs. However, when the rate of shell addition does not exceed the rate of shell destruction, high rate of destruction probably will be coupled with limited time-averaging.

Therefore, limited time-averaging of SFDs can be good news for interpretation of size patterns and some aspects of population dynamics in the fossil record. Even when the total range of shell ages exceeds the scale of the population dynamics, the frequency distribution of shell ages is dominated mostly by recently died cohorts (Olszewski, 1999). This is the simple consequence of the fact that the dead fossils that were produced first will have suffered higher taphonomic destruction than those produced last, so the contribution of older material to the total will be reduced progressively (Olszewski, 1999). Thus, data about size patterns and population structure of fossil taxa can be more reliable than is usually thought.

When the SFD is used to infer some aspects of population dynamics, necessary assumptions about the unbiased proportion of individual size classes need to be corroborated by independent taphonomic data. Low/high abundance of juveniles must be interpreted carefully because of the complex relationship between dead-shell production and destruction on a short-term time-scale.

\section{Preservation Potential of Punctate Brachiopods}

Despite the fact that the rate of destruction of punctate brachiopods probably is very high in the San Juan Archi- 
pelago, rapid burial (or escape from the taphonomically active zone), often invoked to be responsible for preservation of fossil assemblages in the fossil record, can lead to entombment of the death assemblages. Therefore, actualistic studies of modern death assemblages of brachiopods should provide decent analogues of brachiopod fossil assemblages. The implication that the death assemblage of the brachiopod Terebratalia transversa is dominated by the most-recent cohorts, based on this study of their SFDs and the fidelity study of the whole mollusk-brachiopod assemblage (Kowalewski et al., 2003), has important consequences for its preservation potential. Where rapid burial does not occur, relative abundance of punctate brachiopods probably will be underrepresented in the fossil record in comparison to taxa with organic-poor shell structures (e.g., most bivalves; Taylor and Layman, 1972; Kidwell and Brenchley, 1994). If they do not undergo long-term time-averaging due to their high rate of destruction, punctate brachiopods, when preserved, can provide high-fidelity information (reciprocal taphonomic model; Kowalewski, 1997; see Kowalewski, 1996b, for an analogous case in lingulids). High rates of destruction of punctate brachiopods due to shell maceration also have been documented from other temperate siliciclastic settings (Stewart, 1981; Witman and Cooper, 1983; Collins, 1986; Emig, 1990; Gaspard, 1996). This seemingly contrasts with good preservation and abundance of punctate brachiopods in Mesozoic and Cenozoic deposits (e.g., Gaspard, 1988; Aberhan, 1992; Garcia, 1993; Hagdorn and Simon, 1993; Sulser and Meyer, 1998; Fürsich et al., 2001; Zonneveld, 2001). Unless all occurrences of punctate brachiopods are explained by mechanically or biologically induced rapid burial, it is necessary to infer some other taphonomic pathways inhibiting the high rate of their destruction. Recently, this view has been supported by amino-acid dating, which indicates that terebratulid brachiopods are time-averaged on a scale of thousands years on a Holocene tropical carbonate shelf (SW Brazil; Kowalewski et al., 2002; Carroll et al., 2003). Olszewski $(1999,2004)$ suggested that the coefficient of taphonomic decay derived from radiometric or calibrated amino-acid dating measures the likelihood of exhumation rather than the inherent rate of shell destruction. Nevertheless, the disparity between taphonomic preservation and degree of time-averaging of punctate brachiopods from different modern latitudinal settings should be tested in the future because it could have profound consequences for evaluating temporal and spatial distribution patterns of fossil punctate brachiopods.

Relatively high values of shell organic matter also are typical of impunctate brachiopods (2.65\%; Jope, 1965), but shell maceration has not been proven in impunctate brachiopods. The high rate of destruction in punctate brachiopods could be enhanced structurally by organic-lined perforations (punctae), or this difference may be related to variations in the physical and chemical properties of the organic matrix between punctate and impunctate brachiopods (Jope, 1965; Cusack et al., 1997). In previous studies of the evolution and ecology of brachiopods, differential preservation of articulate brachiopods with different shell structures mostly was ignored as a possible factor influencing their occurrence. This potential difference in postmortem durability of articulate brachiopods with different shell structure and shell biochemistry can lead to substan- tial variation in their preservation potential and should be investigated in the future. The low preservation potential of punctate brachiopods could have important implications for the fidelity of their fossil record. In comparison to impunctate brachiopods, morphologic disparity, taxonomic diversity, or relative within-community abundance of punctate brachiopods can be strongly biased.

\section{CONCLUSIONS}

(1) Size frequency distribution of death assemblages is a powerful tool for the evaluation of magnitude and variation of taphonomic processes, both from the point of view of information loss and paleoenvironmental interpretation. In previous work, the fidelity of SFDs of brachiopod death assemblages was interpreted in terms of environmental factors only. This study indicates that the evaluation of both extrinsic (environmental) and intrinsic (postmortem durability and population dynamics related to dead-shell production) factors is necessary for understanding variations in fidelity patterns of death assemblages.

(2) SFDs of death assemblages differ significantly between shallower (36-45 m), hard-bottom and deeper (64$84 \mathrm{~m}$ ), mixed-bottom, temperate siliciclastic habitats of the San Juan Archipelago. In contrast, SFDs of death assemblages within each of these settings are relatively similar, indicating different patterns and processes of taphonomic preservation between these two settings, most probably related to substrate characteristics, water energy, and/or net rate of sedimentation.

(3) There are significant differences between SFDs of life and death assemblages in hard-bottom habitats, where the fidelity of SFDs of life and death brachiopod assemblages is very low and is shaped primarily by taphonomic processes. Juvenile specimens are underrepresented, most probably due to winnowing and mechanical destruction.

(4) SFDs of death assemblages from mixed-bottom settings are characterized by relatively high fidelity with respect to the skewness and modality, and original variations of population structure can be inferred.

(5) There is a difference between the preservation of smaller and larger specimens. Smaller specimens are uniformly well preserved. Due to their high rate of destruction, the preserved fraction of juveniles probably represents the most recently died cohorts. Larger specimens exhibit higher variation in taphonomic damage, which indicates size-selectivity of taphonomic processes and disharmonious time-averaging of death assemblages with regard to the relative abundance of size classes.

(6) Despite differential postmortem durability of small and large specimens, SFDs of death assemblages from mixed-bottom settings correspond to SFDs of life assemblages. This fact, together with data about high rates of brachiopod destruction, indicates limited time-averaging and a snapshot-like character of SFDs of death assemblages.

(7) Due to a short taphonomic half-life, preservation of juveniles will depend on the interplay between the variations in dead-shell production related to population dynamics and the rate of shell destruction. A simple deterministic model can be used to explain disparity in the absolute and relative abundance of juveniles in two or more 
taxa that are characterized by differences in the rate of destruction and/or dead-shell production frequency.

(8) This preservation pattern has significant implications for evaluating distribution patterns of punctate brachiopods in the fossil record. In settings comparable to that of the San Juan Archipelago, with a high rate of punctate brachiopod destruction, death assemblages of punctate brachiopods will be characterized by a high degree of fidelity. If removal from the taphonomic active zone is not fast, the distribution pattern of punctate brachiopods may be strongly biased.

\section{ACKNOWLEDGEMENTS}

I am very thankful to Mike Kowalewski and Mike LaBarbera for their supervision, encouragement, and support during this taphonomic project and their critical reviews of the manuscript. I am grateful to all participants of the taphonomic project for their help and inspiration. I thank two anonymous PALAIOS reviewers and Tom Olszewski for critical reviews, and Franz T. Fürsich for comments and discussions on early drafts of this manuscript. I am indebted to University of Washington and Friday Harbor Laboratories for their financial support that made my study at San Juan Islands possible.

\section{REFERENCES}

ABERHAN, M., 1992, Palökologie und zeitliche Verbreiterung benthischer Faunengemeinschaften im Unterjura von Chile: Beringeria, v. 5, p. 3-174.

AGUiRRE, J., and JimÉNEZ, A.P., 1997, Census assemblages in hardbottom coastal communities: a case study from the Plio-Pleistocene Mediterranean: PALAIOS, v. 12, p. 598-608.

AlEXANDER, R.R., 1977, Growth, morphology and ecology of Paleozoic and Mesozoic opportunistic species of brachiopods from IdahoUtah: Journal of Paleontology, v. 51, p. 1133-1149.

AleXANDERsson, E.T., 1979, Marine maceration of skeletal carbonates in the Skagerrak, North Sea: Sedimentology, v. 26, p. 845852.

Alvarez, F., 1986, Population structure of three species of the genus Plicathyris (Brachiopoda: Athyridacea) from the Devonian of the Cantabrian Zone (NW Spain) and their significance: in Racheboeuf, P.R., and Emig, C.C., eds., Les Brachiopodes Fossiles et Actuels; Actes du 1er Congres International sur les Brachiopods; Biostratigraphie du Paléozoique, v. 4: Universite de Bretagne Occidentale, Brest, p. 167-177.

ARUA, I., 1982, Borings and shell damage in Eocene Gastropoda: southeastern Nigeria: Palaeogeography, Palaeoclimatology, $\mathrm{Pa}-$ laeoecology, v. 38, p. 269-282.

AsgaARD, U., and BRomley, R.G., 1991, Population dynamics and autecology of "Rhynchonella" triangularis, a Late Cretaceous rocky coast brachiopod: in MacKinnon, D.I., Lee, D.E., and Campbell, J.D., eds., Brachiopods Through Time: A.A. Balkema, Rotterdam, p. 247-252.

AtKins, D., 1959, The growth stages of the lophophore and loop of the brachiopod Terebratalia transversa (Sowerby): Journal of Morphology, v. 105, p. 401-426.

BeHrensmeyer, A.K., Kidwell, S.M., and Gastaldo, R.A., 2000, Taphonomy and paleobiology 2000: Paleobiology v. 26,4, Supplement, p. 103-144.

BERNARD, F.R., 1972, The living Brachiopoda of British Columbia: Syesis, v. 5, p. 73-82.

BEST, M.M.R., and KIDWELL, S.M., 2000a, Bivalve taphonomy in tropical mixed siliciclastic-carbonate settings; I, Environmental variation in shell condition: Paleobiology, v. 26, p. 80-102.

BEST, M.M.R., and KIDWELL, S.M., 2000b, Bivalve taphonomy in tropical mixed siliciclastic-carbonate settings; II, Effect of bivalve life habits and shell types: Paleobiology, v. 26, p. 103-115.
BitneR, M.A., 2002, Size-frequency distributions of Miocene micromorphic brachiopods: interpretation tool for population dynamics: Marine Ecology, v. 23, p. 19-30.

Bosence, D.W.J., 1979, Live and dead faunas from coralline algal gravels, Co. Galway, Eire: Palaeontology, v. 22, p. 449-478.

BRETT, C.E., 1988, Paleoecology and evolution of marine hard substrate communities: an overview: PALAIOS, v. 3, p. 374-378.

BRYAN, J.R., 1992, Origin and paleoecology of Maastrichtian rockground and chalk facies in south- central Alabama: PALAIOS, v. 7, p. 67-76.

BuENING, N., and CARLSON, S.J., 1992, Geochemical investigation of growth in selected Recent articulate brachiopods: Lethaia, v. 25, p. 331-345.

CADÉE, G.C., 1982a, Low juvenile mortality in fossil brachiopods, some comments: Interne Verslagen Nederlands Instituut voor Onderzoek der zee, Texel, v. 3, p. 1-29.

CADÉE, G.C., 1982b, Population dynamics in brachiopods: Lethaia, v. 16, p. 65-66.

Carroll, M., Kowalewsiri, M., Simões, M.G., and Goodfriend, G.A., 2003, Quantitative estimates of time-averaging in terebratulid brachiopod shell accumulations from a modern tropical shelf: Paleobiology, v. 29, p. 381-402.

CAte, A.S., and Evans, I., 1992, Life histories and population structure of Pennsylvanian brachiopods from north-central Texas as determined from size-frequency analysis: Journal of Paleontology, v. 66, p. $868-880$.

Colgan, M.W., 1987, Coral reef recovery on Guam (Micronesia) after catastrophic predation by Acanthaster planci: Ecology, v. 68, p. 1592-1605.

CoLLINS, M.J., 1986, Post mortality strength loss in shells of the Recent articulate brachiopod Terebratulina retusa (L.) from the west coast of Scotland: in Racheboeuf, P.R., and Emig, C.C., eds., Les Brachiopodes Fossiles et Actuels; Actes du 1er Congres International sur les Brachiopods; Biostratigraphie du Paléozoique, v. 4: Universite de Bretagne Occidentale, Brest, p. 209-218.

ColLINS, M.J., 1991, Growth rate and substrate-related mortality of a benthic brachiopod population: Lethaia, v. 24, p. 1-11.

Craig, G.Y., and HALlAM, A., 1963, Size-frequency and growth-ring analyses of Mytilus edulis and Cardium edule, and their palaeoecological significance: Palaeontology, v. 6, p. 731-750.

Craig, G.Y., and Oertel, G., 1966, Deterministic models of living and fossil populations of animals: Quarterly Journal of Geological Society of London, v. 122, p. 315-355.

Cummins, H., Powell, E.N., Stanton, R.J., JR., and StafF, G., 1986a, The size-frequency distributions in palaeoecology: effects of taphonomic processes during formation of molluscan death assemblages in Texas bays: Palaeontology, v. 29, p. 495-518.

Cummins, H., Powell, E.N., Stanton, R.J., JR., and StaFF, G., 1986b, The rate of taphonomic loss in modern benthic habitats: how much of the potentially preservable community is preserved?: Palaeogeography, Palaeoclimatology, Palaeoecology, v. 52, p. 291-320.

CURRY, G.B., 1982, Ecology and population structure of the Recent brachiopod Terebratulina from Scotland: Palaeontology, v. 25, p. 227-246.

CuRRY, G.B., 1984, Brachiopod growth and climate: in Brenchley, P., ed., Fossils and Climate: John Wiley and Sons, Chichester and New York, p. 75-83.

CusAck, M., Walton, D., and CuRRY, G.B., 1997, Shell biochemistry: in Williams, A., Brunton, C.H.C., and Carlson, S.J., eds., Treatise on Invertebrate Paleontology, Part H. Brachiopoda Revised, Volume 1: Geological Society of America and University of Kansas Press, Boulder and Lawrence, p. 243-266.

CutLer, A.H., 1993, Mathematical models of temporal mixing in the fossil record: in Kidwell, S.M., and Behrensmeyer, A.K., eds., Taphonomic Approaches to Time Resolution in Fossil Assemblages: Short Courses in Paleontology No. 6, Paleontological Society, Knoxville, p. 169-187.

DALEY, G., 1993, Passive deterioration of shelly material: a study of the Recent Eastern Pacific articulate brachiopod Terebratalia transversa Sowerby: PALAIOS, v. 8, p. 226-232.

DoDD, J.R., and STANTON, R.J., JR., 1990, Paleoecology: Concepts and Applications, $5^{\text {th }}$ ed.: John Wiley and Sons, New York, 502 p.

DOHERTY, J., 1979, A demographic study of a subtidal population of 
the New Zealand articulate brachiopod Terebratella inconspicua: Marine Biology, v. 52, p. 331-342.

Edinger, E.N., PANDOlFI, J.M., and Kelley, R.A., 2001, Community structure of Quaternary coral reefs compared with Recent life and death assemblages: Paleobiology, v. 27, p. 669-694.

EmiG, C.C., 1990, Examples of post-mortality alteration in Recent brachiopod shells and (paleo)ecological consequences: Marine Biology, v. 104, p. 233-238.

FAGERSTROM, J.A., 1964, Fossil communities in paleoecology: their recognition and significance: Geological Society of America Bulletin, v. 75, p. 1197-1216.

FARINATi, E.A., SAlvadOR, A., and GinsBerg, S.S., 1992, Mass mortality of a Holocene Tagelus plebeius (Mollusca, Bivalvia) population in the Bahía Blanca Estuary, Argentina: Marine Geology, v. 10, p. 301-308.

FLESSA, K.W., and FÜRSICH, F.T., 1991, Quantitative analyses of molluscan communities and taphocoenoses of Bahia la Choya (Gulf of California, Sonora, Mexico): Zitteliana, v. 18, p. 79-88.

FÜRSICH, F.T., and ABERHAN, M., 1990, Significance of time-averaging for palaeocommunity analysis: Lethaia, v. 23, p. 143-152.

FÜRSICH, F.T., BERNDT, R., ScheURER, T., and GAHR, M., 2001, Comparative ecological analysis of Toarcian (Lower Jurassic) benthic faunas from southern France and east-central Spain: Lethaia, v. 34, p. 169-199.

GARCIA, J.-P., 1993, Les variations du niveau marin sur le Bassin de Paris au Bathonien-Callovien: impacts sur les communautés benthiques et sur l'evolution des ornithellides (Terebratellidina): Mémoires Géologiques de l'Université de Dijon, v. 17, p. 1-307.

GASPARD, D., 1988, Sellithyridinae Terebratulidae du Crétacé d'Europe Occidentale - dynamique des populations-systématique et evolution: Cahiers de Paléontologie, Editions du CRNS, $243 \mathrm{p}$.

GASPARD, D., 1996, Taphonomy of some Cretaceous and Recent brachiopods: in Copper, P., and Jin, J., eds., Brachiopods: Proceedings of the $3^{\text {rd }}$ International Brachiopod Congress, A.A. Balkema, Rotterdam, p. 95-102.

GiLINSKY, N.L., and BENNINGTON, J.B., 1994, Estimating numbers of whole individuals from collections of body parts: a taphonomic limitation of the paleontological record: Paleobiology, v. 20, p. 245-258.

Greenstein, B.J., and PANDOLFI, J.M., 1997, Preservation of community structure in modern reef coral life and death assemblages of the Florida Keys: implications for the Quaternary fossil record of coral reefs: Bulletin of Marine Science, v. 61, p. 431-452.

HAGDORN, H., and SimON, T., 1993, Ökostratigraphische Leitbänke im Oberen Muschelkalk: in Hagdorn, H., and Seilacher, A., eds., Muschelkalk. Schöntaler Symposium: Sönderbande der Gesellschaft für Naturkunde in Württemberg, p. 193-208.

HALLAM, A., 1967, The interpretation of size-frequency distributions in molluscan death assemblages: Palaeontology, v. 10, p. 25-42.

HallaM, A., 1972, Models involving population dynamics: in Schopf, T.J.M., ed., Models in Paleobiology: Freeman, Cooper and Company, San Francisco, p. 62-80.

HANNISDAL, B., 2004, Clams and brachiopods: chips that pass out of sight: PALAIOS, v. 19, p. 507-513.

James, M.A., Ansell, A.D., Collins, M.J., CurRy, G.B., PeCK, L.S., and RHODES, M.C., 1992, Biology of living brachiopods: Advances in Marine Biology, v. 28, p. 175-387.

JoPE, H.M., 1965, Composition of brachiopod shell: in Moore, R.C., ed., Treatise on Invertebrate Paleontology, Part H. Brachiopoda, Volume 1: University of Kansas Press, Lawrence, p. 156-164.

KIDWELL, S.M., 2001, Preservation of species abundance in marine death assemblages: Science, v. 294, p. 1091-1094.

KIDWELL, S.M., 2002, Time-averaged molluscan death assemblages: palimpsests of richness, snapshots of abundance: Geology, v. 30, p. 803-806.

Kidwell, S.M., and Bosence, D.W.J., 1991, Taphonomy and time-averaging of marine shelly faunas: in Allison, P.A., and Briggs, D.E.G., eds., Taphonomy: Releasing the Data Locked in the Fossil Record: Topics in Geobiology 9, Plenum Press, London, p. 115-209.

KIDWELl, S.M., and BRENCHLEY, P.J., 1994, Patterns in bioclastic accumulation through the Phanerozoic: changes in input or in destruction?: Geology, v. 22, p. 1139-1143
KIDWELL, S.M., and FlESSA, K.W., 1996, The quality of the fossil record: populations, species, and communities: Annual Reviews in Earth and Planetary Sciences, v. 24, p. 433-464.

KowALEWSKI, M., 1996a, Time-averaging, overcompleteness, and the geological record: Journal of Geology, v. 104, p. 317-326.

KowALEWSKI, M., 1996b, Taphonomy of a living fossil: the lingulide brachiopod Glottidia palmeri Dall from Baja California, Mexico: PALAIOS, v. 11, p. 244-265.

KowALEWSKI, M., 1997, The reciprocal taphonomic model: Lethaia, v. 30, p. $86-88$.

Kowalewski, M., Carroll, M., Casazza, L., Gupta, N., Hannisdal, B., Hendy, A., Krause, R.A., JR., LaBarbera, M., Lazo, D.G. Messina, C., Puchalski, S., Rothfus, T.A., SÄlgeback, J., StemPIEN, J., TERRY, R.C., and TOMAŠOVÝCH, A., 2003, Quantitative fidelity of brachiopod-mollusk assemblages from modern subtidal environments of San Juan Islands, USA: Journal of Taphonomy, v. 1, p. $43-65$.

Kowalewski, M., Simões, M.G., Carroll, M., and Rodland, D.L., 2002, Abundant brachiopods on a tropical, upwelling-influenced shelf (Southeast Brazilian Bight, South Atlantic): PALAIOS, v. 17, p. 277-286.

KREBS, C.J., 2001, Ecology, the Experimental Analysis of Distribution and Abundance, $5^{\text {th }}$ ed.: Cummings, San Francisco, 695 p.

LABARBERA, M., 1978, Brachiopod orientation to water movement: functional morphology: Lethaia, v. 11, p. 67-79.

LEE, D.E., 1978, Aspects of the ecology and paleoecology of the brachiopod Notosaria nigricans: Journal of the Royal Society of New Zealand, v. 8, p. 395-417.

LEE, D.E., ScholZ, J., and Gordon, D.P., 1997, Paleoecology of a late Eocene mobile rockground biota from North Otago, New Zealand: PALAIOS, v. 12 , p. 568-581.

LIE, U., 1974, Distribution and structure of benthic assemblages in Puget Sound, Washington, USA: Marine Biology, v. 26, p. 203-223.

LONG, J.A., 1964, The embryology of three species representing three superfamilies of articulate Brachiopoda: Unpublished Ph.D. Thesis, University of Washington, Seattle, $185 \mathrm{p}$.

Martin, R.E., 1999, Taphonomy: A Process Approach: Cambridge Paleobiology Series 4, Cambridge University Press, Cambridge, $508 \mathrm{p}$.

Meldahl, K.H., Flessa, K.W., and Cutler, A.H., 1997, Time-averaging and postmortem skeletal survival in benthic fossil assemblages: quantitative comparisons among Holocene environments: Paleobiology, v. 23, p. 207-229.

Miller, A.I., and Cummins, H., 1990, A numerical model for the formation of fossil assemblages: estimating the amount of post-mortem transport along environmental gradients: PALAIOS, v. 5, p. 303-316.

Miller, A.I., and Cummins, H., 1993, Using numerical models to evaluate the consequences of time- averaging in marine fossil assemblages: in Kidwell, S.M., and Behrensmeyer, A.K., eds., Taphonomic Approaches to Time Resolution in Fossil Assemblages: Short Courses in Paleontology No. 6, Paleontological Society, Knoxville, p. 151-168.

Miller, W., III, and DU BAR, J.R., 1988, Size-frequency distributions in paleoecology: a reply: Lethaia, v. 21, p. 416

NoBLE, J.P.A., and LoGAN, A., 1981, Size-frequency distributions and taphonomy of brachiopods: a recent model: Palaeogeography, $\mathrm{Pa}-$ laeoclimatology, Palaeoecology, v. 36, p. 87-105.

NoE-NYGAARD, N., SURLYK, F., and PIASECKI, S., 1987, Bivalve mass mortality caused by toxic dinoflagellate blooms in a Berriasian-Valanginian lagoon, Bornholm, Denmark: PALAIOS, v. 2, p. 263-273.

OLSON, E.C., 1957, Size-frequency distribution of samples of extinct organisms: Journal of Geology, v. 65, p. 309-333.

OLsZEWSKI, T., 1999, Taking advantage of time-averaging: Paleobiology, v. 25 , p. 226-238.

OlszewsKI, T., 2004, Modeling the influence of taphonomic destruction, reworking, and burial on time-averaging in fossil accumulations: PALAIOS, v. 19, p. 39-50.

OLSZEWSKI, T., and WEST, R.R., 1997, Influence of transportation and time-averaging in fossil assemblages from the Pennsylvanian of Oklahoma: Lethaia, v. 30, p. 315-329.

PAINE, R.T., 1969, Growth and size distribution of the brachiopod Terebratalia transversa Sowerby: Pacific Science, v. 23, p. 337-343.

Pandolfi, J.M., and Greenstein, B.J., 1997a, Taphonomic alter- 
ation of reef corals: effects of reef environment and coral growth form. I. The Great Barrier Reef: PALAIOS, v. 12, p. 27-42.

PANDOLFI, J.M., and GREensteIn, B.J., 1997b, Preservation of community structure in death assemblages of deeper-water Caribbean reef corals: Limnology and Oceanography, v. 42, p. 1505-1516.

PANDOLFI, J.M., and Minchin, P.R., 1995, A comparison of taxonomic composition and diversity between reef coral life and death assemblages in Madang Lagoon, Papua New Guinea: Paleogeography, Palaeoclimatology, Palaeoecology, v. 119, p. 321-341.

PeCK, L.S., Clarke, A., and Holmes, L.J., 1987, Size, shape and the distribution of organic matter in the Recent Antarctic brachiopod Liothyrella uva: Lethaia, v. 20, p. 33-40.

Peterson, C.H., 1985, Patterns of lagoonal bivalve mortality after heavy sedimentation and their paleoecological significance: Paleobiology, v. 11, p. 139-153.

PowELL, E.N., 1992, A model for death assemblage formation: can sediment shelliness be explained?: Journal of Marine Research, v. 50, p. 229-265.

Powell E.N., CAllender, W.R., and Stanton, R.J., JR., 1998, Can shallow- and deep-water chemoautotrophic and heterotrophic communities be discriminated in the fossil record?: Paleogeography, Palaeoclimatology, Palaeoecology, v. 144, p. 85-114.

Powell, E.N., Staff, G.M., Davies, D.J., and CAllender, W.R., 1989, Macrobenthic death assemblages in modern marine environments: formation, interpretation, and application: Reviews in Aquatic Sciences, v. 1, p. 555-589.

Powell, E.N., Staff, G.M., Stanton, R.J., JR., and Callender, W.R., 2001, Application of trophic transfer efficiency and age structure in the trophic analysis of fossil assemblages: Lethaia, v. 34, p. 97-118.

Powell, E.N., and StANTON, R.J., JR., 1996, The application of sizefrequency distribution and energy flow in paleoecologic analysis: an example using parautochthonous death assemblages from a variable salinity bay: Paleogeography, Palaeoclimatology, $\mathrm{Pa}-$ laeoecology, v. 124, p. 195-231.

Powell, E.N., Stanton, R.J., JR., Davies, D., and Logan, A., 1986, Effect of a large larval settlement and catastrophic mortality on the ecologic record of the community in the death assemblage: Estuarine, Coastal and Shelf Science, v. 23, p. 513-525.

RichaRds, R.P., and BAMBACH, R.K., 1975, Population dynamics of some Paleozoic brachiopods and their paleoecological significance: Journal of Paleontology, v. 49, p. 775-798.

RICHARDSON, J.R., 1997, Ecology of articulated brachiopods: in Williams, A., Brunton, C.H.C., and Carlson, S.J., eds., Treatise on Invertebrate Paleontology, Part H. Brachiopoda Revised, Volume 1: Geological Society of America and University of Kansas Press, Boulder and Lawrence, p. 441-462.

RoKOP, F.J., 1977, Seasonal reproduction of the brachiopod Frieleia halli and the deep scaphopod Cadulus californicus at bathyal depths in the deep sea: Marine Biology, v. 43, p. 237-246.

Shimoyama, S., 1985, Size-frequency distribution of living populations and dead shell assemblages in a marine intertidal sand snail, Umbonium (Suchium) moniliferum (Lamarck), and their palaeoecological significance: Palaeogeography, Palaeoclimatology, Palaeoecology, v. 49, p. 327-353.

SimôES, M.G., and KowALEWSKI, M., 1998, Shell beds as paleoecological puzzles: a case study from the Upper Permian of the Paraná Basin, Brazil: Facies, v. 38, p. 175-196.

Smith, A.M., and NELSON, C.S., 2003, Effects of early sea-floor processes on the taphonomy of temperate shelf skeletal carbonate deposits: Earth-Science Reviews, v. 63, p. 1-31.

STAFF, G.M., and PowELL, E.N., 2000, Onshore-offshore trends in the size-frequency distribution of death assemblages: northwestern Gulf of Mexico: Gulf of Mexico Science, v. 18, p. 104-129.
STEWART, I.R., 1981, Population structure of articulate brachiopod species from soft and hard substrates: New Zealand Journal of Zoology, v. 8, p. 197-207.

SUlSER, H., and MeYer C., 1998, Taxonomy and palaeoecology of terebratulid brachiopods (Sellithyris subsella-group) from the Late Jurassic of northwestern Switzerland: Eclogae Geologica Helvetica, v. 91, p. 439-451.

SURLYK, F., 1972, Morphological adaptations and population structures of the Danish Chalk brachiopods (Maastrichtian, Upper Cretaceous): Kongelige Danske Videnskabernes Selskab, Biologiske Skrifter, v. 19, p. 2-57.

SURLYK, F., 1974, Life habit, feeding mechanism and population structure of the Cretaceous brachiopod genus Aemula: Palaeogeography, Palaeoclimatology, Palaeoecology, v. 15, p. 185-203.

TADDEI RUGGIERO, E., 2001, Brachiopods of the Isca submarine cave: observations during ten years: in Brunton, C.H.C., Cocks, L.R.M., and Long, S.L., eds., Brachiopods: Past and Present: (The Systematic Association Special Volume Series 63): Taylor and Francis, London, p. 261-267.

TANABE, K., and ARIMURA, E., 1987, Ecology of four infaunal bivalve species in the Recent intertidal zone, Shikoku, Japan: Palaeogeography, Palaeoclimatology, Palaeoecology, v. 60, p. 219-230.

TAYLOR, J.D., and LAYMAN, M., 1972, The mechanical properties of bivalve (Mollusca) shell structures: Palaeontology, v. 15, p. 73-87.

TAYLOR, P.D., and WILsON, M.A., 2003, Palaeoecology and evolution of marine hard substrate communities: Earth-Science Reviews, v. 62, p. 1-103.

THAYER, C.W., 1975, Size-frequency and population structure of brachiopods: Palaeogeography, Palaeoclimatology, Palaeoecology, v. 17, p. 139-148.

THAYER, C.W., 1977, Recruitment, growth and mortality of a living articulate brachiopod, with implications for the interpretation of survivorship curves: Paleobiology, v. 3, p. 98-109.

Thomson, R.E., 1981, Oceanography of the British Columbia Coast: Department of Fisheries and Oceans, Ottawa, $291 \mathrm{p}$.

TunNiCLIFFE, V., and WiLson, K., 1988, Brachiopod populations: distribution in fjords of British Columbia (Canada) and tolerance of low oxygen concentrations: Marine Ecology—Progress Series, v. 47, p. 117-128.

WALKER, K.R., and BAMBACH, R.K., 1971, The significance of fossil assemblages from fine-grained sediments: time-averaged communities: Geological Society of America Abstracts with Programs, v. 3, p. 783-784.

WiLsON, M.A., and TAYLOR, P.D., 2001, Palaeoecology of hard substrate faunas from the Cretaceous Quahlah Formation of the Oman Mountains: Palaeontology, v. 44, p. 21-41.

WitMAN, J.D., and CoOPER, R.A., 1983, Disturbance and contrasting patterns of population structure in the brachiopod Terebratulina septentrionalis (Couthouy) from two subtidal habitats: Journal of Experimental Marine Biology and Ecology, v. 73, p. 57-79.

ZonNeveld, J.-P., 2001, Middle Triassic biostromes from the Liard Formation, British Columbia, Canada: oldest examples from the Mesozoic of NW Pangea: Sedimentary Geology, v. 145, p. 317-341.

Zuschin, M., HohenegGer, J., and STEININGER, F.F., 2000, A comparison of living and dead molluscs on coral reef associated hard substrata in the northern Red Sea-implications for the fossil record: Palaeogeography, Palaeoclimatology, Palaeoecology, v. 159, p. $167-190$.

Zuschin, M., and Oliver, P.G., 2003, Fidelity of molluscan life and death assemblages on sublittoral hard substrata around granitic islands of the Seychelles: Lethaia, v. 36, p. 133-150.

ACCEPTED FEBRUARY 2, 2004

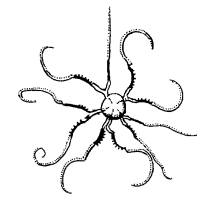

